Atmos. Chem. Phys., 18, 18079-18100, 2018

https://doi.org/10.5194/acp-18-18079-2018

(C) Author(s) 2018. This work is distributed under

the Creative Commons Attribution 4.0 License.

\title{
Modeling organic aerosol concentrations and properties during winter 2014 in the northwestern Mediterranean region
}

\author{
Mounir Chrit ${ }^{1}$, Karine Sartelet ${ }^{1}$, Jean Sciare ${ }^{2,3}$, Marwa Majdi ${ }^{1,5}$, José Nicolas ${ }^{2}$, Jean-Eudes Petit ${ }^{2,4}$, and \\ François Dulac ${ }^{2}$ \\ ${ }^{1}$ CEREA, joint laboratory Ecole des Ponts ParisTech - EDF R\&D, Université Paris-Est, \\ 77455 Champs sur Marne, France \\ ${ }^{2}$ LSCE, CNRS-CEA-UVSQ, Institut Pierre Simon Laplace (IPSL), Université Paris-Saclay, \\ Gif-sur-Yvette, France \\ ${ }^{3}$ EEWRC, The Cyprus Institute, Nicosia, Cyprus \\ ${ }^{4}$ INERIS, Parc Technologique ALATA, 60550 Verneuil-en-Halatte, France \\ ${ }^{5}$ Laboratoire de Métérologie Dynamique - IPSL, Sorbonne Université, Centre national de \\ la recherche scientifique (CNRS), Unité Mixte de Recherche (UMR) 8539, \\ Ecole Polytechnique, Paris, France
}

Correspondence: Mounir Chrit (mounir.chrit@enpc.fr)

Received: 7 February 2018 - Discussion started: 26 April 2018

Revised: 17 November 2018 - Accepted: 23 November 2018 - Published: 20 December 2018

\begin{abstract}
Organic aerosols are measured at a remote site (Ersa) on the cape of Corsica in the northwestern Mediterranean basin during the winter campaign of 2014 of the CHemistry and AeRosols Mediterranean EXperiment (CharMEx), when high organic concentrations from anthropogenic origins are observed. This work aims to represent the observed organic aerosol concentrations and properties (oxidation state) using the air-quality model Polyphemus with a surrogate approach for secondary organic aerosol (SOA) formation. Because intermediate and semi-volatile organic compounds (I/S-VOCs) are the main precursors of SOAs at Ersa during winter 2014, different parameterizations to represent the emission and aging of I/S-VOCs were implemented in the chemistry-transport model of Polyphemus (different volatility distribution emissions and single-step oxidation vs multi-step oxidation within a volatility basis set VBS - framework, inclusion of non-traditional volatile organic compounds - NTVOCs). Simulations using the different parameterizations are compared to each other and to the measurements (concentration and oxidation state). The highly observed organic concentrations are well reproduced in all the parameterizations. They are slightly underestimated in most parameterizations. The volatility distribution at emissions influences the concentrations more strongly than the
\end{abstract}

choice of the parameterization that may be used for aging (single-step oxidation vs multi-step oxidation), stressing the importance of an accurate characterization of emissions. Assuming the volatility distribution of sectors other than residential heating to be the same as residential heating may lead to a strong underestimation of organic concentrations. The observed organic oxidation and oxygenation states are strongly underestimated in all simulations, even when multigenerational aging of I/S-VOCs from all sectors is modeled. This suggests that uncertainties in the emissions and aging of I/S-VOC emissions remain to be elucidated, with a potential role of formation of organic nitrate and low-volatility highly oxygenated organic molecules.

\section{Introduction}

Organic aerosols (OAs) are one of the main compound of submicron particulate matter $\left(\mathrm{PM}_{1}\right.$; Jimenez et al., 2009). Their primary fraction originates mostly from combustion sources, such as traffic and residential heating. However, large uncertainties remain regarding their emissions (Jathar et al., 2014; Gentner et al., 2017; Shrivastava et al., 2017; Tsimpidi et al., 2017). POAs have been considered non- 
volatile in emissions inventories and chemistry-transport models (CTMs); however, recent studies have provided clear evidence that a large portion of POA emissions partition between the gas and the particle phases (Robinson et al., 2007). Organic species that compose POAs are often classified depending on their volatility: intermediate volatility organic compounds (IVOCs; with saturation concentration $C^{*}$ in the range $10^{3}-10^{6} \mu \mathrm{g} \mathrm{m}^{-3}$ ), semi-volatile organic compounds (SVOCs; with saturation concentration $C^{*}$ in the range 0.1$10^{3} \mu \mathrm{g} \mathrm{m}^{-3}$ ), or low-volatility organic compounds (LVOCs; with saturation concentration $C^{*}$ lower than $0.1 \mu \mathrm{g} \mathrm{m}^{-3}$; Lipsky and Robinson, 2006; Grieshop et al., 2009; Huffman et al., 2009; Cappa and Jimenez, 2010; Fountoukis et al., 2014; Tsimpidi et al., 2010; Woody et al., 2016; Ciarelli et al., 2017a, b).

OAs originate not only from the partitioning of POAs between the gas and the particle phases but also from secondary organic aerosol (SOA) formation through the gas-to-particle partitioning of the oxidation products of biogenic and anthropogenic volatile organic compounds (VOCs) and intermediate and semi volatile organic compounds (I/S-VOCs). The main biogenic VOC precursors are terpenes ( $\alpha$-pinene, $\beta$-pinene, limonene, humulene) and isoprene (Shrivastava et al., 2017), while the main anthropogenic VOC precursors are aromatics (e.g., toluene and xylene; Dawson et al., 2016; Gentner et al., 2017).

Available measurements and modeling studies are useful in elucidating the composition and origin of OAs in different seasons (Couvidat et al., 2012; Hayes et al., 2015; Canonaco et al., 2015; Chrit et al., 2017; Ciarelli et al., 2017b). Indeed, over the Mediterranean region, the oxidation of biogenic VOCs may dominate the formation of OAs during the summer (El Haddad et al., 2013; Minguillón et al., 2016; Chrit et al., 2017). Chrit et al. (2017) found that I/S-VOC emissions do not influence the concentrations of OAs in summer over the Mediterranean region much, but biogenic SOAs prevail. Because biogenic emissions are low in winter, Canonaco et al. (2015) demonstrated a clear shift in the SOA origin between summer and winter during a measurement campaign from February 2012 to February 2013 conducted in Zurich using the Aerosol Chemical Speciation Monitor (ACSM; Ng et al., 2011) measurements. This last study notably highlights the importance of biogenic VOC emissions and biogenic SOA production in summer as well as the importance of residential heating in winter. Ciarelli et al. (2017a) performed a source apportionment study at the European scale and revealed that residential combustion (mainly related to wood burning) contributed about $60 \%-70 \%$ to SOA formation during the winter, whereas non-residential combustion and road-transportation sector contributed about $30 \%-40 \%$ to SOA formation. Moreover, residential heating can also be a source of POAs, which may make up a large fraction $(20 \%$ to $90 \%)$ of the submicron particulate matter in winter (Murphy et al., 2006; May et al., 2013a; Denier van der Gon et al., 2015b; Shrivastava et al., 2017).
Modeling OA concentrations in winter is challenging, because it mostly involves the characterization of $\mathrm{I} / \mathrm{S}-\mathrm{VOC}$ emissions and aging. Standard gridded emission inventories, such as those of the European Monitoring and Evaluation Programme (EMEP, http://www.emep.int, last access: 10 December 2018) over Europe, do not yet include I/S-VOC emissions, and their emissions are still highly uncertain. For example, Denier van der Gon et al. (2015a) estimated that emissions from residential wood combustion were underestimated by a factor of 2-3 in the 2005 EUCAARI inventory. As an indirect method of accounting for the missing organic emissions in the absence of precise emission inventories, numerous modeling studies estimate the I/S-VOC emissions from POA emissions (Couvidat et al., 2012; Bergström et al., 2012; Koo et al., 2014; Zhu et al., 2016; Ciarelli et al., 2017a) or more recently from VOC emissions (Zhao et al., 2015, 2016; Ots et al., 2016; Murphy et al., 2017). A ratio of I/S-VOC/POA of 1.5 has been used in several airquality studies (Bergström et al., 2012; Koo et al., 2014; Zhu et al., 2016; Ciarelli et al., 2017a). For example, Zhu et al. (2016) simulated the particle composition over greater Paris during the winter MEGAPOLI campaign, and they found that simulated OAs agreed well with observed OAs when gas-phase I/S-VOCs emissions are estimated using a ratio $\mathrm{I} / \mathrm{S}-\mathrm{VOC} / \mathrm{POA}$ of 1.5 , as derived following the measurements at the tailpipe of vehicles representative of the average French vehicle (Kim et al., 2016). However, various ratios are used to better fit the measurements. For example, over Europe, Couvidat et al. (2012) used a I/S-VOC/POA ratio of 4 , but they also used a ratio of 6 in a sensitivity simulation to better fit the observed OA concentrations in winter. Koo et al. (2014) used an IVOC / POA ratio of 1.5, but they also used a ratio of 3 in their high-IVOC emission scenario.

The atmospheric evolution (also known as aging) of I/SVOCs as well as their impacts on atmospheric OA concentrations remain poorly characterized (Murphy et al., 2006) and deserve a better understanding. A widely used approach to model the aging of I/S-VOCs in CTMs is the volatility basis set (VBS) approach (Donahue et al., 2006). I/S-VOCs are divided into several classes of volatility where each class is represented by a surrogate. When oxidized by the hydroxyl radical, it leads to the formation of surrogates of lower volatility classes. This approach tends to lead to an overestimation of simulated organic concentrations (Cholakian et al., 2018) if fragmentation is not considered (formation of highvolatility surrogates during the oxidation). Although the onedimensional basis set (1-D VBS) accounts for the volatility of the surrogates, it does not allow the representation of varying oxidation levels of OAs. The prognostic tool to date that is more powerful, the two-dimensional VBS approach (2-D VBS), although it is computationally burdensome, describes not only the aging of I/S-VOCs using not only the volatility property $\left(C^{*}\right)$ but also the oxidation level (the oxygento-carbon ratio $\mathrm{O}: \mathrm{C}$ ), taking into account three competing processes: functionalization, oligomerization and fragmenta- 
tion (Donahue et al., 2012). Koo et al. (2014) developed a 1.5-D aging VBS-type scheme that accounts for multigenerational aging, including functionalization, oligomerization and fragmentation, and that represents both the volatility and the oxidation properties of the surrogates. When oxidized by a hydroxyl radical, each surrogate leads to the formation of more-oxidized and less-volatile surrogates with a reduced carbon number. Functionalization and fragmentation are implicitly taken into account in this approach because of the increase of the oxygen number and the decrease of the carbon number of the surrogates formed. The 1.5-D VBS module is implemented within two widely used CTMs, namely the Comprehensive Air Quality Model with extensions (CAMx; ENVIRON, 2011) and the Community Multiscale Air Quality Modeling System (CMAQ; Byun and Ching, 1999). Couvidat et al. (2012, 2013b, 2018) and Zhu et al. (2016) used a simplified aging scheme with three volatility bins. When oxidized by the hydroxyl radical, each surrogate forms a lessvolatile and more-oxidized surrogate that does not undergo multigenerational aging. This simplified aging scheme is implemented in the two widely used CTMs, Polyphemus (Chrit et al., 2017) and Chimere (Couvidat et al., 2018).

In winter, when anthropogenic emissions impact air quality the most, anthropogenic emissions such as toluene and xylene may also form SOAs, although they may be much less efficient than I/S-VOCs (Couvidat et al., 2013a; Sartelet et al., 2018). To take into account the emissions and aging of anthropogenic VOCs that are usually not considered in CTMs (phenol; naphthalene; $m-, o-, p$-cresol; etc., Ciarelli et al. (2017b) modified the approach of Koo et al. (2014) by considering non-traditional VOCs (NTVOCs). They are VOCs or IVOCs, not usually taken into account in CTMs, with a saturation concentration in the low range of IVOCs.

Following Bruns et al. (2016), Ciarelli et al. (2017b) estimated these NTVOCs using chamber experiments as the mixture of phenol; $m$-, $o-, \quad p$-cresol; $m$-, $o$ , $\quad$-benzenediol/2-methylfuraldehyde; dimethylphenols; guaiacol/methylbenzenediols; naphthalene; 2methylnaphthalene/1-methylnaphthalene; acenaphthylene; syringol; biphenyl/acenaphthene; and dimethylnaphthalene. Furthermore, they estimated the ratio NTVOC/SVOC, where SVOC is the primary semi-volatile organic matter, to be about 4.75 .

The oxidation level of OAs is important, because it is indicative of the degree of hygroscopicity, surface tension (Jimenez et al., 2009), and radiative property of the OAs in addition to its ability to act as cloud condensation nuclei (CCN) over the Mediterranean (Jimenez et al., 2009; Duplissy et al., 2011; Wong et al., 2011). Chrit et al. (2017) showed that, in summer in the western Mediterranean region, OAs are highly oxidized and oxygenated. The CTM Polyphemus and Polair3d used in their study does represent this high oxidation level of OAs after adding the formation processes of highly oxidized species (autoxidation) and organic nitrate formation to the model.
The particle oxidation state is represented by the organicmass-to-organic-carbon ratio (OM : OC). According to Gilardoni et al. (2009) and Kroll et al. (2011), OM : OC is an index of the contribution of heteroatoms $(\mathrm{O}, \mathrm{H}, \mathrm{S}, \mathrm{N}$, etc.) to the organic mass; chemically processed and aged particles are expected to have higher OM : OC ratios compared to freshly emitted and unprocessed aerosols. The oxygenation state is represented by the oxygen-to-carbon ratio $(\mathrm{O}: \mathrm{C})$. It indicates the contribution of oxygen to organic molecules and the ability of carbon atoms to form bonds with oxygen.

Although the organic matter to organic carbon ratio (OM : OC) was first believed to lie between 1.2 and 1.4 (Grosjean and Friedlander, 1975), numerous studies (Turpin and Lim, 2001; El-Zanan et al., 2005; Aiken et al., 2008; Couvidat et al., 2012; Tost and Pringle, 2012; Canagaratna et al., 2015; Tsimpidi et al., 2018) show that OM:OC is approximately 1.6 for urban aerosols and 2.1 for non urban aerosols. Zhang et al. (2005a) developed an algorithm to deconvolve the mass spectra of OAs obtained with an Aerodyne $^{\mathrm{TM}}$ aerosol mass spectrometer (AMS) in order to estimate the mass concentrations of hydrocarbon-like and oxygenated organic aerosols (HOAs and OOAs). The mass of HOAs represents primary sources, with an OM:OC ratio close to 1.2 and $\mathrm{O}: \mathrm{C}$ ratio close to 0.1 , while the mass of OOAs represents secondary sources (aged and oxygenated) with an OM : OC ratio close to 2.2 and an $\mathrm{O}: \mathrm{C}$ ratio close to 1 (Aiken et al., 2008). Using this technique, Zhang et al. (2005b) found an average OM : OC ratio of 1.8 in Pittsburgh in September. Over Europe, Crippa et al. (2014) found that secondary OAs are dominant in the OA fraction, with primary sources contributing to less than $30 \%$ of the total mass fraction. Xing et al. (2013) measured a ratio OM : OC ratio over 14 cities throughout China and found that in summer, OM : OC is nearly $1.75 \pm 0.13$, while the ratio is lower in winter $(1.59 \pm 0.18)$. The $\mathrm{OM}: \mathrm{OC}$ ratio is lower during winter due to the slow oxidation process owing to the low temperatures in addition the low biogenic contribution to OA mass during winter. At Ersa, over the Mediterranean and during the summer, Chrit et al. (2017) found high OM : OC and $\mathrm{O}: \mathrm{C}$ ratios (2.5 and 1 respectively). They are due to aged biogenic OAs, which Chrit et al. (2017) were able to represent by adding the formation of extremely low-volatility species and organic nitrate to the model and by considering the formation of organosulfate.

Quantifying the effect of I/S-VOC emissions and their impact on the atmospheric organic budget as well as the OA oxidation and oxygenation levels during different seasons is challenging in spite of the recent advances concerning the description of I/S-VOCs (Stockwell et al., 2015; Ciarelli et al., $2017 b)$. This work aims to evaluate how commonly used parameterizations and assumptions of I/S-VOCs emissions and aging perform to model the OA concentrations and properties in the western Mediterranean region in winter. To that end, the CTM from the air-quality platform Polyphemus is 
used with different parameterizations of I/S-VOCs emissions and aging.

This paper is structured as follows. Section 2 presents the setup of the air-quality model used and reference measurements. Section 3 presents the different emissions and aging mechanisms used to describe the evolution of I/S-VOCs as well as the comparison method. Section 4 compares the simulated concentrations, which are compositions of OAs for the simulations using the different parameterizations. Finally, Sect. 5 compares the measured and simulated OM : OC and $\mathrm{O}: \mathrm{C}$ ratios.

\section{Model and measurement setup}

The period of interest of this study is January-March 2014, hereafter referred to as the winter 2014 campaign.

\subsection{General model setup}

The Polyphemus and Polair3d air-quality model is used, with a similar setup to Chrit et al. (2017). Transport and dry and wet deposition are modeled following Sartelet et al. (2007). The Carbon Bond 05 model is used for gas-phase chemistry. Semi-volatile organic compound formation mechanisms from five SOA gaseous precursors, namely isoprene, monoterpenes, sesquiterpenes, and aromatic compounds, and intermediate and semi-volatile organic compounds from anthropogenic emissions (Kim et al., 2011; Couvidat et al., 2012), are added to CB05 model. These five precursors are modeled with a few surrogates as proxies to represent all the species. The aerosol dynamics (coagulation and condensation and evaporation) are modeled using the size-resolved aerosol model (SIREAM; Debry et al., 2007) based on a sectional approach with an aerosol distribution of 24 sections of bound diameters: $0.01,0.0141,0.0199,0.0281,0.0398$, $0.0562,0.0794,0.1121,0.1585,0.199,0.25,0.316,0.4$, $0.5,0.63,0.79,1.0,1.2589,1.5849,1.9953,2.5119,3.5481$, $5.0119,7.0795$ and $10.0 \mu \mathrm{m}$.

The thermodynamic model used for the condensation and evaporation of inorganic aerosol is ISORROPIA v1 (Nenes et al., 1998), and the gas-particle partitioning of SOAs is computed with SOAP (Couvidat and Sartelet, 2015). In order to compute the gas-particle partitioning of both inorganics and organics, a bulk equilibrium approach is adopted. After condensation and evaporation, the mass is redistributed among size bins using the moving diameter algorithm (Jacobson, 1997).

The simulations are run between 1 January and 2 April 2014 for both the nesting (Europe) and the nested (Mediterranean) domains. The simulation domains (Europe and Mediterranean) and the spatial resolution used in the present study are the same as the ones used in Chrit et al. (2017). The spatial resolutions used for the European and Mediterranean domains are $0.5^{\circ} \times 0.5^{\circ}$ and $0.125^{\circ} \times 0.125^{\circ}$ along longitude and latitude. 14 vertical levels are used for both domains from the ground to $12 \mathrm{~km}$. The heights of the cell interfaces are $0,30,60,100,150,200,300,500,750$, 1000, 1500, 2400, 3500, 6000 and $12000 \mathrm{~m}$.

Boundary conditions for the European domain are obtained from the global chemistry-transport model MOZART v4.0 (Horowitz et al., 2003; https://www.acom.ucar.edu/ wrf-chem/mozart.shtml, last access: 10 December 2018). The European simulation provides initial and boundary conditions to the Mediterranean one. The European Centre for Medium-Range Weather Forecasts (ECMWF) model provides the meteorological fields. The Troen and Mahrt parameterization (Troen and Mahrt, 1986) is used to compute the vertical diffusion. The land cover is modeled using the Global Land Cover 2000 (GLC-2000; http://forobs.jrc. ec.europa.eu/products/glc2000/data_access.php, last access: 10 December 2018) data set. Sea-salt emissions are parameterized following Jaeglé et al. (2011) and are assumed to be composed of sodium, chloride and sulfate (Schwier et al., 2015). Biogenic emissions are estimated with the Model of Emissions of Gases and Aerosols from Nature (MEGAN, Guenther et al., 2006). Anthropogenic emissions are generated using the EDGAR-HTAP_V2 inventory for 2010 (http://edgar.jrc.ec.europa.eu/htap_v2/, last access: 10 December 2018). The monthly and daily temporal distribution for the different activity sectors are obtained from GENEMIS (1994), and the hourly temporal distribution is obtained from Sartelet et al. (2012). $\mathrm{NO}_{x}, \mathrm{SO}_{x}$ and $\mathrm{PM}_{2.5}$ emissions are speciated as described in Chrit et al. (2017). I/S-VOC gas-phase emissions are estimated from the POA emissions from residential heating by multiplying them by a constant factor assumed to be 1.5 in the default simulation. The total (gas and particle) I/S-VOC is therefore equal to 2.5 times the original POA.

As described in Sect. 3.5, different values will be used and compared for I/S-VOC gas-phase emissions from residential heating and from other sectors. The I/S-VOCs emissions from residential heating are assumed to be those of the sector "htap_6_residential" of the EDGAR-HTAP_V2 inventory. The emissions from this sector (shown in Fig. 1) concern the emissions from heating and cooling and equipment and lighting of buildings as well as waste treatment. The I/SVOC emissions from residential heating (RH) are obtained from the POA emissions of sector 6 by multiplying them by a constant factor represented by $R_{\mathrm{RH}}=\mathrm{I} / \mathrm{S}-\mathrm{VOC} / \mathrm{POA}$. These emissions over the Mediterranean domain are located over big cities (Marseille, Milan, Rome, etc.). I/S-VOC emissions from the six other anthropogenic sources (shown in Fig. 1) are estimated from the POA emissions by multiplying them by a constant factor noted $R=\mathrm{I} / \mathrm{S}-\mathrm{VOC} / \mathrm{POA}$. These emissions are located over big cities and along the main traffic routes as well as on the shipping routes linking Marseille to Ajaccio and Bastia. Different estimations of $R$ and $R_{\mathrm{RH}}$ will be used as well as different approaches to represent the aging of I/S-VOCs (Sect. 3). 
(a)

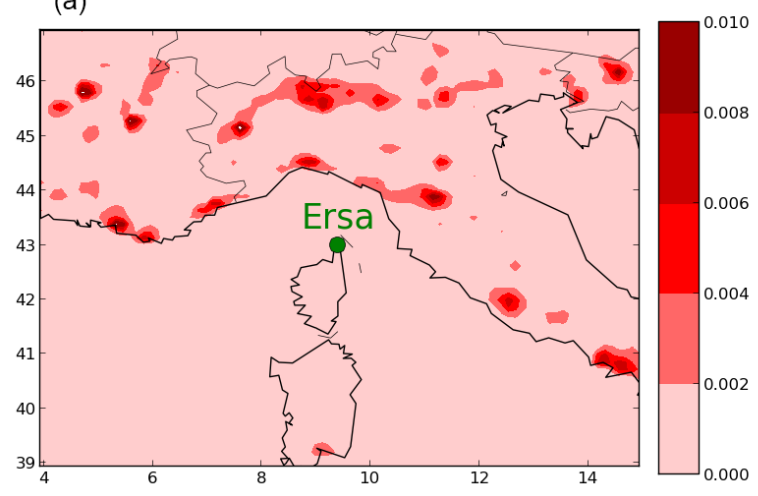

(b)

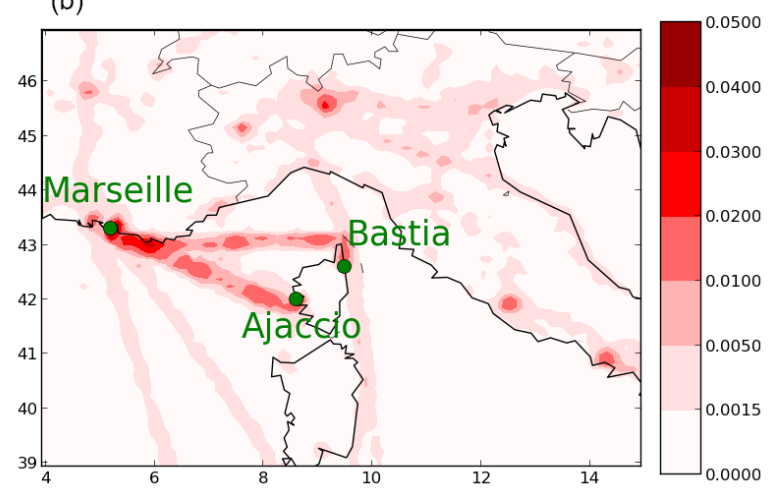

Figure 1. Surface emissions of POAs from the residential heating sector (a) and from the other six anthropogenic sectors (b) during winter 2014. The emissions are in $\mu \mathrm{g} \mathrm{m}^{-2} \mathrm{~s}^{-1}$.

\subsection{Measurement setup}

The ground-based measurements were performed in the framework of the CHemistry and AeRosols Mediterranean EXperiment (ChArMEx) at Ersa $\left(42^{\circ} 58^{\prime} \mathrm{N}, 9^{\circ} 21.8^{\prime} \mathrm{E}\right)$ on a ridge at the northern tip of the island of Corsica, at an altitude of about $530 \mathrm{~m}$ a.s.l. The ground-based comparisons are performed by comparing the measured and modeled concentrations at the model cell closest to the station $\left(42^{\circ} 52 \mathrm{~N}\right.$, $9^{\circ} 22^{\prime} 30^{\prime \prime} \mathrm{E}, 494 \mathrm{~m}$ a.s.1.), as detailed in Chrit et al. (2017). An Aerodyne ${ }^{\mathrm{TM}}$ ACSM was used in order to measure the near real-time mass concentration and chemical composition of aerosols with aerodynamic diameters between 70 and $1000 \mathrm{~nm}$, with a time resolution of $30 \mathrm{~min}(\mathrm{Ng}$ et al., 2011). This instrument has been continuously running at Ersa between June 2012 and July 2014 (Nicolas, 2013), with an onsite setup similar to that presented in Michoud et al. (2017). A recent intercomparison exercise, in which the ACSM used in this study has successfully taken part, reports an expanded uncertainty of $19 \%$ for OM (Crenn et al., 2015). OM: OC and $\mathrm{O}: \mathrm{C}$ ratios are estimated using these measurements, following the methodology provided in Kroll et al. (2011). Although Crenn et al. (2015) and Fröhlich et al. (2015) have shown consistent results (e.g., satisfactorily $Z$-scores) in terms of fragmentation pattern, higher discrepancies were observed for $f_{44}$ (mass fraction of $m / z 44$ ), which is an essential variable in the calculation of these elemental ratios. In this respect, results are presented with an uncertainty which can be estimated as being twice the one of PM (i.e., around $40 \%$ ). The measurements are compared to concentrations and properties of particles of diameters between 0.01 and $1 \mu \mathrm{m}$.

\subsection{Model and measurement comparison method}

To evaluate the performance of the model, we compare model simulation results to measurements at the Ersa site using a variety of performance statistical indicators. These indicators are: the simulated mean $(\bar{s})$, the root-mean-square error (RMSE), the correlation coefficient (corr), the mean fractional bias (MFB) and the mean fractional error (MFE). Table A1 of Appendix A lists the key statistical indicators definitions used in the model-to-data intercomparison. Furthermore, the criteria of Boylan and Russell (2006), which is detailed in Table A2 of Appendix A, is used to assess the performance of the simulations.

\section{Modeling of I/S-VOC emissions and aging}

In order to understand the behavior of the different parameterizations commonly used in CTMs to represent emissions and aging of I/S-VOCs in the western Mediterranean region, several simulations using different parameterizations, described in the following sections, are compared. These parameterizations are those described in Couvidat et al. (2012), Koo et al. (2014) and Ciarelli et al. (2017b). The differences concern the emission ratios used to estimate $\mathrm{I} / \mathrm{S}$-VOCs from POAs ( $R$ and $R_{\mathrm{RH}}$ ), the aging scheme (one step or multi-generational), the modeling of NTVOCs and the ratio $\mathrm{OM}$ : OC and volatility distribution at emissions.

\subsection{One-step oxidation scheme}

The one-step oxidation mechanism of Couvidat et al. (2012) is based on the fitting of the curve of dilution of POAs from diesel exhaust of Robinson et al. (2007). I/S-VOCs are modeled with three surrogate species POAIP, POAmP and POAhP of different volatilities chosen to fit the dilution curve of POAs from diesel exhaust of Robinson et al. (2007) and characterized by their saturation concentrations $(0.91,86.21$ and $3225.80 \mu \mathrm{g} \mathrm{m}^{-3}$, respectively).

The properties of the primary and aged I/S-VOCs are shown in Table B1 of Appendix B. The aging of each of these primary surrogates is modeled by a one-step $\mathrm{OH}$-oxidation reaction in the gas phase (Appendix B), leading to the for- 
mation of secondary surrogates SOAIP, SOAmP and SOAhP. Once formed, these secondary surrogates do not undergo further oxidations. Compared to the primary surrogates, the volatility of the secondary surrogates is reduced by a factor of 100, and their molecular weight is increased by $40 \%$ (Grieshop et al., 2009; Couvidat et al., 2012) to represent functionalization and fragmentation.

\subsection{Multi-generational step oxidation scheme}

In sensitivity simulations, for anthropogenic I/S-VOC emissions, the oxidation mechanism is based on the hybrid volatility basis set (1.5-D VBS) approach developed by Koo et al. (2014). This mechanism combines the simplicity of the 1-D VBS with the ability to describe evolution of OAs in the 2-D space of oxidation state and volatility. This basis set uses five volatility surrogates, characterized by saturation concentrations varying between 0.1 and $1000 \mu \mathrm{g} \mathrm{m}^{-3}$. The surrogates VAP0, VAP1, VAP2, VAP3 and VAP4 refer to the primary surrogates, and VASO, VAS1, VAS2, VAS3 and VAS4 refer to the secondary ones. Table $\mathrm{C} 1$ of Appendix C lists their properties.

In the scheme developed by Koo et al. (2014), the OHoxidation of the primary surrogates leads to a mixture of primary and secondary surrogates of lower volatility. The carbon number (and oxygen number for secondary surrogates) of the lower volatility surrogate decreases (and increases for secondary surrogates), indicating that functionalization and fragmentation are implicitly accounted for. This mechanism is detailed in Appendix C.

\subsection{Multi-generational step oxidation scheme for residential heating}

In sensitivity simulations, for anthropogenic I/S-VOC emissions from residential heating, the VBS model developed by Ciarelli et al. (2017b) is also used. As in the previously detailed multi-step oxidation scheme, five surrogates with volatilities characterized by saturation concentrations extending from 0.1 to $1000 \mu \mathrm{g} \mathrm{m}^{-3}$ are used. The primary surrogates (BBPOA1, BBPOA2, BBPOA3, BBPOA4, $\mathrm{BBPOA5}$ ) react with $\mathrm{OH}$ to form secondary surrogates (BBSOA0, BBSOA1, BBSOA2, BBSOA3, BBSOA4), whose volatility is 1 order of magnitude lower than the primary surrogate. In opposition to the one-step and multi-step oxidation schemes detailed above, here the secondary surrogates may also undergo $\mathrm{OH}$-oxidation forming the secondary surrogate of lower volatility. As in the other schemes, functionalization and fragmentation are taken into account as the carbon and oxygen numbers of the secondary surrogates decreases and increases respectively. The properties of the VBS surrogates are shown in Table D1 of Appendix D, where reactions are also detailed.

Data from recent wood combustion and aging experiments performed in smog chamber by Ciarelli et al. (2017b) show significant contribution of SOAs from non-traditional volatile organic compounds (NTVOCs: phenol; $m-, o-$ , $p$-cresol; $m$-, $\quad o-, \quad p$-benzenediol/2-methylfuraldehyde; dimethylphenols; guaiacol/methylbenzenediols; naphthalene; 2-methylnaphthalene/1-methylnaphthalene; acenaphthylene; syringol; biphenyl/acenaphthene; and dimethylnaphthalene) to OA mass. These NTVOCs are usually not accounted for as SOA precursors in CTMs. The NTVOC mixture saturation concentration is estimated to be $\sim 10^{6} \mu \mathrm{g} \mathrm{m}^{-3}$, falling with the IVOC saturation concentration range limit (Koo et al., 2014; Donahue et al., 2012). NTVOCs emissions are estimated using a ratio of NTVOC / SVOC of 4.75 (Ciarelli et al., 2017b) and their OH-oxidation produces four secondary surrogates of different volatilities. These four surrogates may undergo $\mathrm{OH}$-oxidation leading to the less-volatile and more-oxidized secondary surrogate, similarly to the multi-step oxidation described in Sect. 3.3. This mechanism is detailed in Appendix D, and the surrogates properties are listed in Table D1 of Appendix D.

\subsection{Volatility distribution and properties of primary emissions}

Table 1 shows emission rates of OA precursors averaged over the Mediterranean domain and over the simulation period.

Emissions of I/S-VOCs are allocated into the surrogate compounds detailed in the above sections using emission distribution profiles, which are based on chamber measurements. The distribution of the emission profiles as a function of volatility (saturation concentration) is detailed in Table 2. Two emission profiles are used. The first one corresponds to the measurements of May et al. (2013b) for biomass burning, and it is similar to the emission profile used by Couvidat et al. (2012) for all sectors and by Ciarelli et al. (2017b) for residential heating. The second emission profile corresponds to an average of emission distributions from gasoline and diesel vehicles measured by May et al. (2013c, d), and it is used in Koo et al. (2014). Here, the volatility emission distributions are assigned to a profile number (equal to 1 or 2), depending on whether the volatility profile is similar to the profile from biomass burning emissions of May et al. (2013c) (profile number 2) or whether it is similar to the profile from the vehicle emissions of May et al. (2013d, b) (profile number 1). As shown in Table 2, the emitted I/S-VOCs are less volatile in the profile 1 than in the biomass-burning volatility distribution (profile 2). Depending on the emission sector, the $\mathrm{OM}$ : $\mathrm{OC}$ and $\mathrm{O}: \mathrm{C}$ ratios of the emitted surrogates may differ. For most sectors, such as traffic, the OM : OC and $\mathrm{O}: \mathrm{C}$ ratios are assumed to be low; $\mathrm{OM}: \mathrm{OC}$ is equal to 1.3 in Couvidat et al. (2012). However, for residential heating, the emissions may be more oxidized. The scheme of Ciarelli et al. (2017b) assumes higher OM : OC and O : C rations, as described in Table 3. Here, the $\mathrm{OM}: \mathrm{OC}$ and $\mathrm{O}: \mathrm{C}$ ratios are assigned to a profile number (equal to 1 or 2), depending on 
Table 1. Emission rates of OA precursors averaged temporally and over the Mediterranean domain.

\begin{tabular}{lr}
\hline OA precursor & Emission rate $\left(\mu \mathrm{g} \mathrm{m}^{-2} \mathrm{~s}^{-1}\right)$ \\
\hline VOCs from biogenic and anthropogenic sources & 0.0314 \\
NTVOCs & 0.0062 \\
I/S-VOCs from residential heating & 0.0013 \\
I/S-VOCs from other sources & 0.0030 \\
\hline
\end{tabular}

whether the ratios are similar to the profile from the biomass burning emissions of Ciarelli et al. (2017b)(profile number 2) or whether they are lower (profile number 1).

\subsection{Sensitivity simulations}

The setup of the different simulations is summarized in Table 4. The simulation S1 uses the setup commonly used in air-quality simulations with the Polyphemus platform: the one-step aging scheme of Couvidat et al. (2012) is used for both residential heating and other anthropogenic sectors.

The links between the compared simulations and the sensitivity parameters studied are summarized in Table 5. The simulation S2 is conducted to evaluate the impact of the volatility distribution of emissions. Instead of using a volatility distribution specific of biomass burning for all sectors as in $\mathrm{S} 1$, the volatility distribution specific of car emissions is used for anthropogenic sectors other than residential heating.

The simulation S3 is conducted to evaluate the impact of the aging scheme. The volatility distributions are similar as S2, but multi-generational schemes are used rather than a single-oxidation strep for all anthropogenic sectors.

The simulation $\mathrm{S} 4$ is evaluated to estimate the impact of NTVOCs. It has the same setup as S2 with multi-generational aging, but NTVOCs are taken into account. Even though NTVOCs are added, emissions of I/S-VOCs as modeled by the factor $R_{\mathrm{RH}}$ are kept.

The simulations S5 and S6 are conducted to assess the impact of the I/S-VOC/POA ratio used for residential heating $\left(R_{\mathrm{RH}}\right)$. The simulation S5 has the same setup as the simulation $\mathrm{S} 2$ (single-step oxidation), but it differs in the ratio $R_{\mathrm{RH}}$, which is assumed to be equal to 4 rather than 1.5. The simulation S6 has the same setup as the simulation S4 (multistep oxidation and NTVOCs), but it differs in the ratio $R_{\mathrm{RH}}$, which is assumed to be equal to 4 rather than 1.5.

In terms of the OM: OC ratio, the ratio specific of car emissions is used for emissions from anthropogenic sectors other than residential heating. For residential heating, higher $\mathrm{OM}$ : OC ratios are used in all simulations, except in S1, where the ratio specific of car emissions is used for all sectors.

\section{Organic concentrations}

The spatial distribution of $\mathrm{OM}_{1}$ concentrations averaged over the first 3 months of 2014 (Fig. E1 of Appendix E) shows that high $\mathrm{OM}_{1}$ concentrations are mostly located over big cities, like Marseille $\left(2.0 \mu \mathrm{g} \mathrm{m}^{-3}\right)$, Genoa $\left(1.6 \mu \mathrm{g} \mathrm{m}^{-3}\right)$, Turin $\left(4.3 \mu \mathrm{g} \mathrm{m}^{-3}\right)$, Milan $\left(4.4 \mu \mathrm{g} \mathrm{m}^{-3}\right)$, Rome $\left(2.4 \mu \mathrm{g} \mathrm{m}^{-3}\right)$ and Naples $\left(2.1 \mu \mathrm{g} \mathrm{m}^{-3}\right)$, and along maritime traffic routes, stressing that organics during wintertime are likely to be mostly of anthropogenic origins.

The simulated composition of $\mathrm{OM}_{1}$ at Ersa is shown in Fig. 2 for the simulations S4 and S5. In all simulations, primary and secondary organic aerosols (POAs and SOAs) from anthropogenic I/S-VOCs are the main components of the organic mass (between $60 \%$ and $84 \%$ ). POAs tend to account for almost the same fraction of the organic mass than SOAs (between $46 \%$ and $62 \%$ ). Similarly, in the U.S., Koo et al. (2014) found that the SOAs account for less than half of the modeled OA mass in winter 2005 due to the slow chemical aging during the cold season. Over Europe, in March 2009, Ciarelli et al. (2017a) simulated that POAs account for between $12 \%$ and $68 \%$ of the OAs, with an average value of $38 \%$. The emission sector 6 (residential heating) has a large contribution to OAs (between $31 \%$ and $33 \%$ ). This is also in line with Ciarelli et al. (2017a) who found that, over Europe in March 2009, the contribution of the residential sector to OAs varies between $20 \%$ and $45 \%$, with an average value of $38 \%$. Furthermore, this sector contributes more to SOAs (between $42 \%$ and $52 \%$ of SOAs from I/S-VOCs) than to POAs (between $17 \%$ and $31 \%$ of POAs from I/S-VOCs), because their I/S-VOC emissions are more volatile.

The contribution from aromatic VOCs is low (lower than $3 \%$ ), and when NTVOCs are considered, they represent between $18 \%$ and $21 \%$ of the organic mass. The model simulations performed revealed that, for winter 2014, the biogenic OA fraction is low (15\%-18\%). Ciarelli et al. (2017a) also estimated the biogenic contribution to the organic budget to be between $5 \%$ and $20 \%$ over Europe.

The statistical evaluation of the simulations is shown in Table 6. The model-to-measurement correlation is high for all simulations (between $76 \%$ and $83 \%$ ). The performance criterion is satisfied for all simulations, and the goal criterion is satisfied for $\mathrm{S} 2, \mathrm{~S} 3, \mathrm{~S} 4$ and $\mathrm{S} 5$. The goal criterion is not satisfied for the simulation $\mathrm{S} 1$, which uses single-step oxidation with a biomass-burning-type volatility distribution for all an- 
Table 2. Summary of the volatility distributions of the primary I/S-VOC surrogates. Saturation concentrations are expressed in $\mu g \mathrm{~m}^{-3}$. For each saturation concentration and volatility coefficient, the name of the associated primary surrogate is in square brackets.

\begin{tabular}{|c|c|c|c|c|c|c|c|}
\hline Profil no. & & 1 & 2 & & & 1 & 2 \\
\hline Reference & & May et al. (2013c, d) & Couvidat et al. (2012) & & & May et al. $(2013 c, d)$ & May et al. (2013b) \\
\hline \multirow{5}{*}{ 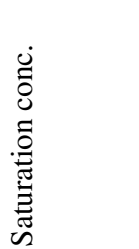 } & 00 & $035[P \cap \triangle 1 P]$ & $025[\mathrm{RPP} \cap 41 \mathrm{Pl}$ & \multirow{5}{*}{ 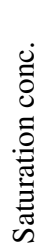 } & 0.1 & 0.15 [VAP0] & 0.20 [BВPOA0] \\
\hline & 0.9 & 0.35 [PUAIP] & 0.25 [BBPUAIP] & & 1 & 0.20 [VAP1] & 0.10 [BBPOA1] \\
\hline & 86.2 & 0.51 [POAmP] & 0.32 [BBPOAmP] & & 10 & 0.31 [VAP2] & 0.10 [BBPOA2] \\
\hline & & & & & 100 & 0.20 [VAP3] & 0.20 [BBPOA3] \\
\hline & 3225.8 & 0.14 [POAhP] & 0.43 [BBPOAhP] & & 1000 & 0.14 [VAP4] & 0.4 [BBPOA4] \\
\hline
\end{tabular}

Table 3. Summary of the OM : OC (and O : C) ratio of the primary I/S-VOC surrogates. Saturation concentrations are expressed in $\mu \mathrm{g} \mathrm{m}^{-3}$. For each saturation concentration and $\mathrm{OM}$ : $\mathrm{OC}$ ratio, the name of the associated primary surrogate is in square brackets.

\begin{tabular}{|c|c|c|c|c|c|c|c|}
\hline Profil no. & & 1 & 2 & & & 1 & 2 \\
\hline Reference & & Couvidat et al. (2012) & & & & Koo et al. (2014) & Ciarelli et al. (2017b) \\
\hline \multirow{5}{*}{ 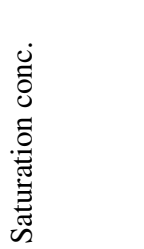 } & 00 & $13(0$ 15) [POAP] & $17(0$ 55) [RRPOAlP] & \multirow{5}{*}{ 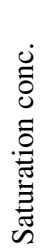 } & 0.1 & $1.36(0.16)$ [VAP0] & $1.64(0.37)$ [BBPOA0] \\
\hline & 0.9 & $1.3(0.15)$ [PUAIP] & 1.1 (U.J5) [BВРUAIP] & & 1 & $1.31(0.12)$ [VAP1] & $1.53(0.29)$ [BBPOA1] \\
\hline & 86.2 & $1.3(0.15)$ [POAmP] & $1.7(0.55)$ [BBPOAmP] & & 10 & $1.26(0.07)$ [VAP2] & $1.44(0.22)$ [BBPOA2] \\
\hline & & & & & & & \\
\hline & 3225.8 & $1.3(0.15)$ [POAhP] & $1.7(0.55)$ [BBPOAhP] & & 1000 & $1.17(0)$ [VAP4] & $1.28(0.09)$ [BBPOA4] \\
\hline
\end{tabular}

thropogenic sectors as well as for the simulation S6, which uses multi-step oxidation with NTVOCs and a high $R_{\mathrm{RH}}$ ratio. The simulation $\mathrm{S} 1$ strongly underestimates the $\mathrm{OM}_{1}$ concentration at Ersa, whereas the simulation S6 strongly overestimates it. All the simulations tend to underestimate the $\mathrm{OM}_{1}$ concentrations at Ersa, except for the two simulations where NTVOCs are taken into account (S4 and S6), which overestimate the $\mathrm{OM}_{1}$ concentrations at Ersa. Because I/SVOC emissions as modeled by the factor $R_{\mathrm{RH}}$ are kept in those simulations, the IVOCs forming SOAs may have been counted twice by adding NTVOCs, explaining the overestimation.

Other CTMs showed the same underestimation of $\mathrm{OM}_{1}$ concentrations during winter over Europe, even when I/SVOC emissions are taken into account (Couvidat et al., 2012; Denier van der Gon et al., 2015a). The CTM CAMx also underestimated the organic concentrations over Europe during February and March 2009 (Ciarelli et al., 2017a), but considerable improvement was found for the modeled OA mass, with the MFB decreasing from $-61 \%$ to $-29 \%$ when the parameterization of Ciarelli et al. (2017b) with NTVOCs was added.

The model-to-measurement comparison during the first 3 months of 2014 is shown in Fig. 3 in terms of the daily concentrations of $\mathrm{OM}_{1}$ at Ersa. Globally, the temporal variations of the simulated concentrations are well reproduced by the model. The simulation S1, which uses single-step oxida- tion with a biomass-burning-type volatility distribution for all anthropogenic sectors, underestimates the peaks. However, the peaks are well reproduced by the simulations S2, S3 and S5. The simulations S4 and S6, which take into account NTVOCs, overestimate the peaks. All simulations underestimate the beginning of the peak between 9 and 15 March, probably due to uncertainties in meteorology, especially rain episodes and changes in the origin of air mass.

As detailed in Sect. 3.5, the differences between the simulations S2 and S1 originate in differences in the volatility distribution of emissions from anthropogenic sectors other than residential heating. In the simulation $\mathrm{S} 2$, a less-volatile distribution is used than in the simulation $\mathrm{S} 1$, leading to larger OA concentrations in the particle phase. This difference in the volatility distribution makes a large difference in the OA concentrations, removing the strong underestimation simulated in simulation $\mathrm{S} 1$ (the MFB is $-55 \%$ in $\mathrm{S} 1$ and only $-23 \%$ in $\mathrm{S} 2$ ).

Considering multi-step aging for all anthropogenic sectors also leads to an increase of $\mathrm{OA}$ concentrations (the $\mathrm{MBF}$ of the simulation $\mathrm{S} 3$ is $-11 \%$, which is lower in absolute value than the simulation $\mathrm{S} 2$ ). However, the influence of the multi-step aging (difference between S2 and S3 shown in Fig. E1 of Appendix E) is smaller than the influence of the volatility distribution (difference between S1 and S2 shown in Fig. E1 of Appendix E). This larger influence of the volatility distribution than the multi-step aging is true 
Table 4. Summary of the parameters used in the different simulations performed.

\begin{tabular}{|c|c|c|c|c|c|c|c|c|c|}
\hline \multirow[b]{2}{*}{ Simulation } & \multicolumn{5}{|c|}{ Residential heating } & \multicolumn{4}{|c|}{ Other anthropogenic sectors } \\
\hline & Aging & $\begin{array}{l}\text { Volatility } \\
\text { profile }\end{array}$ & $R_{\mathrm{RH}}$ & $\begin{array}{c}\text { OM : OC } \\
\text { profile }\end{array}$ & NTVOCs & Aging & $\begin{array}{l}\text { Volatility } \\
\text { profile }\end{array}$ & $R$ & $\begin{array}{c}\text { OM : OC } \\
\text { profile }\end{array}$ \\
\hline S1 & One-step (Couvidat) & 2 & 1.5 & 1 & No & One-step (Couvidat) & 2 & 1.5 & 1 \\
\hline $\mathrm{S} 2$ & One-step (Couvidat) & 2 & 1.5 & 2 & No & One-step (Couvidat) & 1 & 1.5 & 1 \\
\hline S3 & Multi-step (Ciarelli) & 2 & 1.5 & 2 & No & Multi-step (Koo) & 1 & 1.5 & 1 \\
\hline S4 & Multi-step (Ciarelli) & 2 & 1.5 & 2 & Yes & Multi-step (Koo) & 1 & 1.5 & 1 \\
\hline S5 & One-step (Couvidat) & 2 & 4.0 & 2 & No & One-step (Couvidat) & 1 & 1.5 & 1 \\
\hline S6 & Multi-step (Ciarelli) & 2 & 4.0 & 2 & Yes & Multi-step (Koo) & 1 & 1.5 & 1 \\
\hline
\end{tabular}

(a)

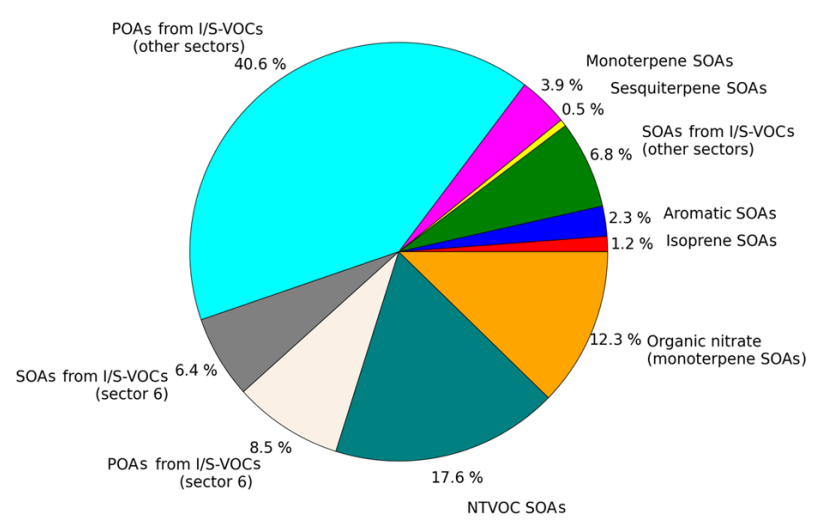

(b)

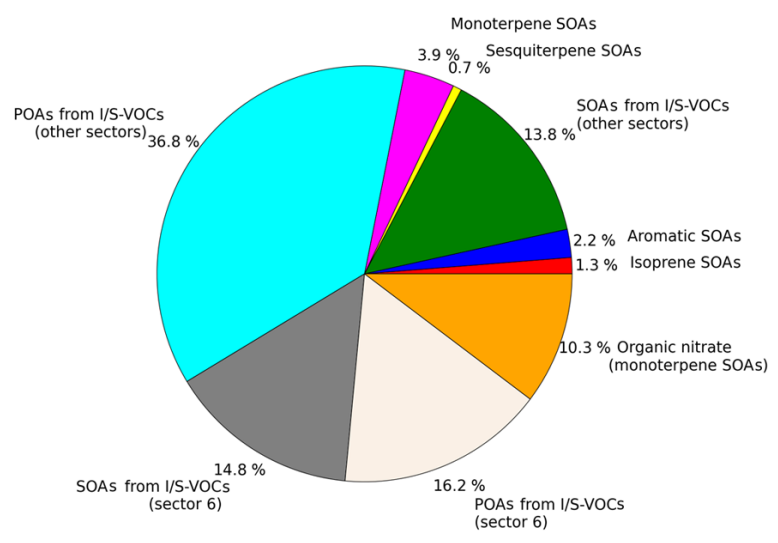

Figure 2. Simulated composition of $\mathrm{OM}_{1}$ during the winter campaign of 2014 for two simulations: S4 (a) and S5 (b).

Table 5. Links between the compared simulations and the sensitivity parameters studied.

\begin{tabular}{ll}
\hline Sensitivity study of the impact of & $\begin{array}{l}\text { Simulations to } \\
\text { be compared }\end{array}$ \\
\hline The volatility distribution of emissions & $\mathrm{S} 1, \mathrm{~S} 2$ \\
The aging scheme & $\mathrm{S} 3, \mathrm{~S} 2$ \\
NTVOCs & $\mathrm{S} 4, \mathrm{~S} 2$ \\
The I/S-VOC / POA ratio & $\mathrm{S} 5, \mathrm{~S} 2$ and S6, S4 \\
\hline
\end{tabular}

not only at Ersa but also over the whole Mediterranean domain, where the average RMSE between the simulations S1 and $\mathrm{S} 2$ is $0.01 \mathrm{\mu g} \mathrm{m}^{-3}$ (impact of volatility), compared to $0.005 \mu \mathrm{g} \mathrm{m}^{-3}$ for the RMSE between the simulations $\mathrm{S} 2$ and S3 (impact of multi-step aging).

At Ersa, increasing the ratio $R_{\mathrm{RH}}$ from 1.5 to 4 (difference between simulation S3 and S2 shown in Fig. E1 of Appendix E) has almost the same impact as considering the multi-step aging (difference between simulations S5 and S2 shown in Fig. E1 of Appendix E), although the statistics are slightly better when the ratio $R_{\mathrm{RH}}$ is increased from 1.5 to 4 than when multi-step aging is considered. However, this is not true over the whole Mediterranean domain, where the impact of increasing the ratio $R_{\mathrm{RH}}$ from 1.5 to 4 is large over cities, whereas the impact of multi-step aging stays small (see Fig. E1 of Appendix E). Over the whole Mediterranean domain, the average RMSE between the simulations S2 and S5 is $0.014 \mu \mathrm{g} \mathrm{m}^{-3}$ (impact of increasing the ratio $R_{\mathrm{RH}}$ from 1.5 to 4 ), compared to $0.005 \mu_{g^{-3}}{ }^{-3}$ for the RMSE between the simulations S2 and S3 (impact of multi-step aging).

Finally, the best statistics in terms of MFE and MFB are obtained for the simulation S5, with a one-step aging scheme, a volatility distribution typical of biomass burning for the residential sector with a ratio $R_{\mathrm{RH}}$ of 4 and a volatility distribution typical of car emissions for other sectors with a ratio $R$ of 1.5 .

\section{Oxidation and oxygenation of organics}

The oxidation state is quantified using two metrics, $\mathrm{OM}$ : OC and O : C, calculated as detailed in Chrit et al. (2017). Figure 4 shows the daily variations of the measured and simulated ratios for the different simulations.

The measurements at Ersa show highly oxidized and oxygenated organics; the measured OM : OC and $\mathrm{O}: \mathrm{C}$ ratios at Ersa are $2.21 \pm 0.09$ and $0.82 \pm 0.07$, respectively. These values are lower than the index measured during summer 2013 by Chrit et al. (2017) $(2.43 \pm 0.07$ and $0.99 \pm 0.06$ for the measured $\mathrm{OM}: \mathrm{OC}$ and $\mathrm{O}: \mathrm{C}$ ratios at Ersa, respectively), 
Table 6. Statistics of model to measurements comparisons for daily $\mathrm{OM}_{1}$ concentrations during the winter campaign of 2014 at Ersa. $\bar{o}$ refers to the observed mean. Other statistical indicators are defined in Table A1 of AppendixA.

\begin{tabular}{|c|c|c|c|c|c|c|c|}
\hline & Simulations & S1 & S2 & S3 & S4 & S5 & S6 \\
\hline$n$ & $\bar{s} \pm \mathrm{RMSE}$ & $0.75 \pm 1.14$ & $1.06 \pm 0.91$ & $1.20 \pm 0.85$ & $1.65 \pm 0.79$ & $1.25 \pm 0.80$ & $2.06 \pm 1.08$ \\
\hline$\stackrel{-}{\stackrel{乛}{*}}$ & Correlation (\%) & 78.3 & 76.7 & 76.2 & 82.4 & 78.8 & 82.7 \\
\hline$\|$ & MFB $(\%)$ & -55 & -23 & -11 & 17 & -7 & 38 \\
\hline 10 & MFE (\%) & 59 & 40 & 37 & 39 & 35 & 48 \\
\hline
\end{tabular}

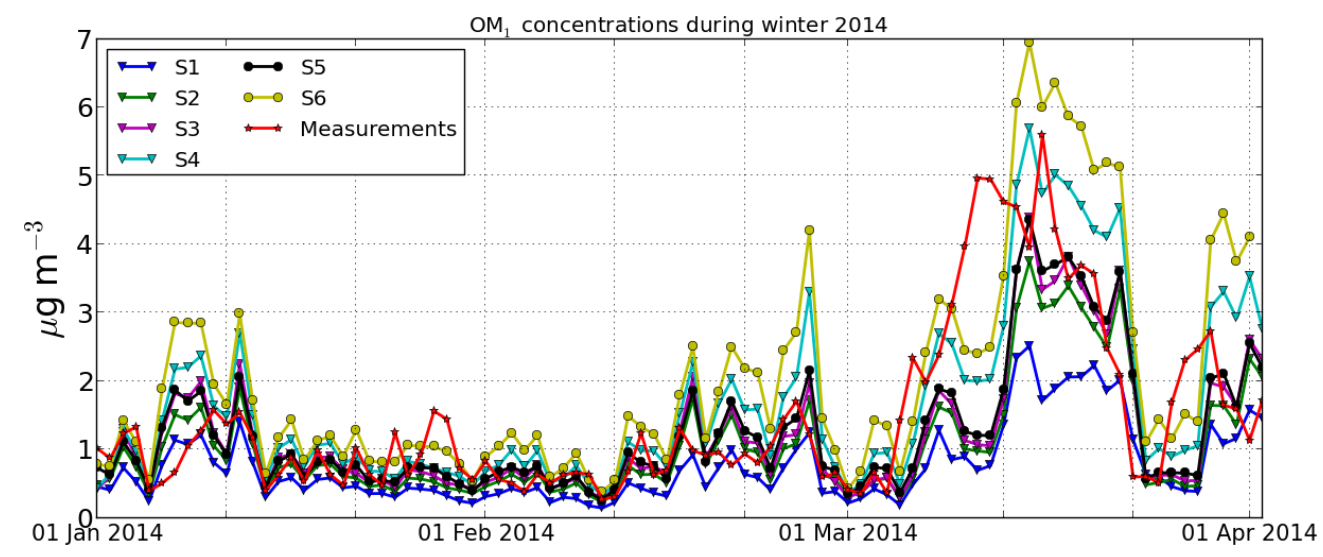

Figure 3. Daily evolution of measured and simulated $\mathrm{OM}_{1}$ concentrations at Ersa from 1 January to 2 April.

due to the slower oxidation process owing to the lower temperatures during winter. The average simulated $\mathrm{OM}: \mathrm{OC}$ and $\mathrm{O}: \mathrm{C}$ ratios are shown in Table 7. Both indices are strongly underestimated by all simulations, due to the high contribution of POAs to the $\mathrm{OM}_{1}$ concentrations (POAs are less volatile and oxygenated than SOAs). The simulations using multi-step aging schemes for $\mathrm{I} / \mathrm{S}-\mathrm{VOC}$ emissions have higher $\mathrm{OM}: \mathrm{OC}$ and $\mathrm{O}: \mathrm{C}$ ratios, although the differences are very low; the $\mathrm{OM}$ : OC ratio is $1.69 \pm 0.53$ in $\mathrm{S} 2$ (single-step) and $1.72 \pm 0.50$ in $\mathrm{S} 3$ (multi-step). Organics in the simulations where the strength of I/S-VOC emissions from residential heating was increased (simulations S5 and S6) and have higher $\mathrm{OM}: \mathrm{OC}$ and $\mathrm{O}: \mathrm{C}$ ratios, because POAs and SOAs from I/S-VOCs from residential heating are more oxidized and oxygenated than POAs and SOAs from other anthropogenic sources. Similarly, organics in the simulations where NTVOCs are taken into account have higher OM : OC and $\mathrm{O}: \mathrm{C}$ ratios, because in the model, NTVOCs lead to very oxidized and oxygenated OAs. However, the simulated ratios $\mathrm{OM}: \mathrm{OC}$ and $\mathrm{O}: \mathrm{C}$ stay underestimated $(1.85 \pm 0.38$ and $0.60 \pm 0.24$ at most, compared to $2.21 \pm 0.09$ and $0.82 \pm 0.07$ in the measurements).

The underestimation of the $\mathrm{O}: \mathrm{C}$ ratio may be due to an underestimation of oxidants' concentrations and secondary aerosol formation. Figure 5 shows that the model tends to underestimate ozone concentrations (the modeled and measured average concentrations between 21 January and
24 February 2014 are 46.2 and $68.0 \mu \mathrm{g} \mathrm{m}^{-3}$ ). However, the $\mathrm{O}: \mathrm{C}$ ratio stays underestimated even during the days where ozone is well modeled. It is difficult to come to a conclusion on the underestimation of oxidants, because measurements were not performed for other oxidants than ozone, such as $\mathrm{OH}$, which probably has other sources than ozone photolysis in winter.

\section{Conclusion}

This study shows a ground-based comparison of both modeled organic concentrations and properties to measurements performed at Ersa (the cape of Corsica, France) during winter 2014. This work aims to evaluate how commonly used parameterizations and assumptions of intermediate and semivolatile organic compound (I/S-VOC) emissions and aging perform in modeling $\mathrm{OA}$ concentrations and properties in the western Mediterranean region in winter. To that end, the chemistry-transport model from the air-quality platform Polyphemus is used with different parameterizations of I/S-VOC emissions and aging (different volatility distribution emissions, single-step oxidation vs multi-step oxidation within a Volatility Basis Set framework, including nontraditional volatile organic compounds NTVOCs). Winter 2014 simulations are performed and compared to measurements obtained with an ACSM at the background station of Ersa in the north of the island of Corsica. In all simulations, 

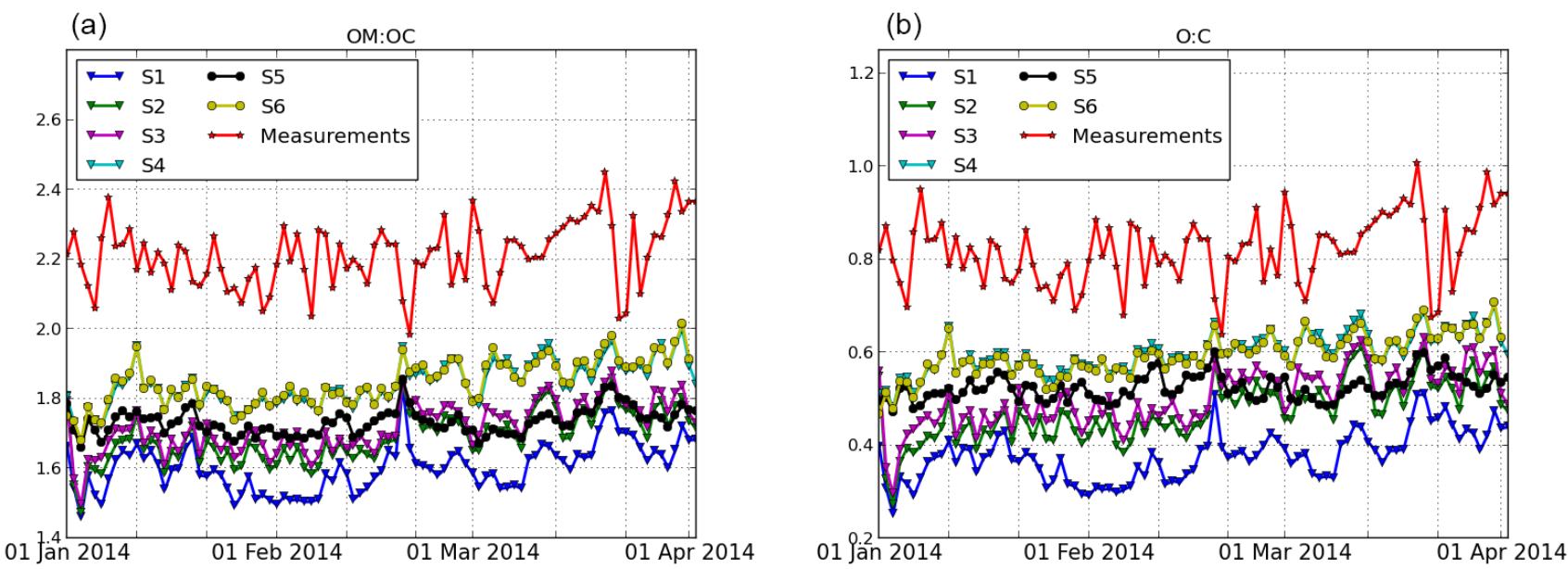

Figure 4. Daily evolution of the ratios OM : OC (a) and O : C (b) from 1 January to 2 April 2014 at Ersa.

Table 7. Daily averages of OM : OC and O : C ratios at Ersa during winter 2014 for the different simulations. The average measured OM : OC ratio is 2.21 and the average measured $\mathrm{O}: \mathrm{C}$ ratio is 0.82 .

\begin{tabular}{lccccccc}
\hline Simulations & S1 & S2 & S3 & S4 & S5 & S6 & Measurements \\
\hline OM : OC & $1.60 \pm 0.62$ & $1.69 \pm 0.53$ & $1.72 \pm 0.50$ & $1.85 \pm 0.38$ & $1.74 \pm 0.49$ & $1.85 \pm 0.38$ & $2.21 \pm 0.09$ \\
O : C & $0.38 \pm 0.45$ & $0.47 \pm 0.36$ & $0.50 \pm 0.33$ & $0.60 \pm 0.23$ & $0.53 \pm 0.31$ & $0.59 \pm 0.24$ & $0.82 \pm 0.07$ \\
\hline
\end{tabular}

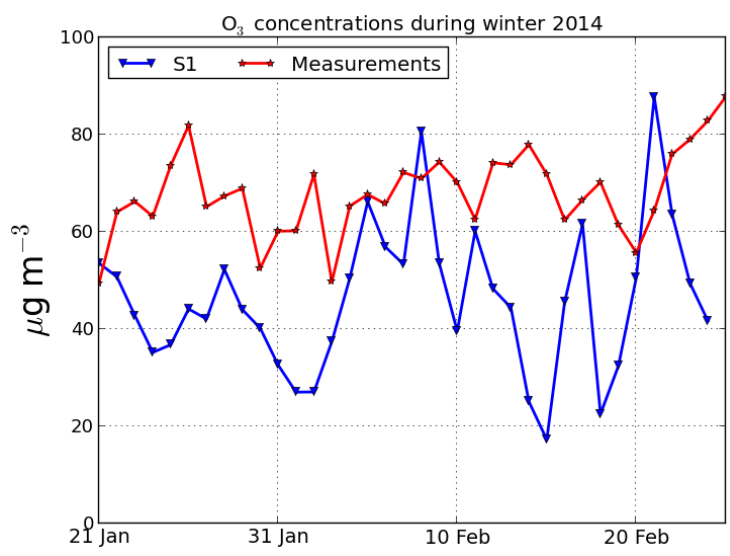

Figure 5. Daily evolution of ozone concentrations from 21 January to 24 February 2014 at Ersa.

OAs at Ersa are mainly from anthropogenic sources (only $15 \%$ to $18 \%$ of OAs are from biogenic sources). The emission sector 6 (residential heating) has a large contribution to OAs (between $31 \%$ and $33 \%$ ). The contribution from aromatic VOCs is low (lower than $3 \%$ ). NTVOCs, as modeled with the parameterization of Ciarelli et al. (2017b), represent between $18 \%$ and $21 \%$ of the organic mass. For most simulations, the concentrations of OAs compare well to the measurements.
Over the whole western Mediterranean domain, the volatility distribution at the emission influences the concentrations more strongly than the choice of the parameterization that may be used for aging (single-step oxidation vs multistep oxidation). Modifying the volatility distribution of sectors other than residential heating leads to a decrease of $29 \%$ in OA concentrations at Ersa, while using the multi-step oxidation parameterization rather than the single-step one leads to an increase of $13 \%$. The best statistics are obtained using two configurations; the first one is a one-step aging scheme, a volatility distribution typical of biomass burning for the residential sector with an I/S-VOC/POA ratio of 4 at emissions, and the second one is a multi-generational aging scheme, a volatility distribution typical of car emissions for other sectors with a $R \mathrm{I} / \mathrm{S}-\mathrm{VOC} / \mathrm{POA}$ ratio of 1.5 at emissions.

Both the $\mathrm{OM}: \mathrm{OC}$ and $\mathrm{O}: \mathrm{C}$ ratios are underestimated at Ersa in all simulations. The largest simulated OM:OC ratio is equal to $1.85 \pm 0.83$, compared to $2.21 \pm 0.09$ in the measurements. For the summer campaign, Chrit et al. (2017) improved the simulated OM: OC ratio by adding the formation mechanisms of organic compounds with extremely low volatility from the autoxidation of monoterpenes and organic nitrate from monoterpene oxidation. Similarly, the formation of organic nitrate and highly oxygenated organic molecules (Molteni et al., 2018) from the autoxidation of aromatic precursors should be added in order to better reproduce the observed OA oxidation and oxygenation levels. 
However, adding these new OA formation pathways may lead to an increase in OA concentrations, suggesting that the actual parameterizations may need to be revisited, for example by better characterizing their deposition. Because the volatility distribution at the emission is the parameter influencing the concentrations the most, further experimental research should therefore focus on characterizing it for the different sectors. The emissions and formation of compounds with very low volatility should also be further investigated to represent the aerosol characteristics observed.

Data availability. Data can be requested from the corresponding author (mounir.chrit@enpc.fr). 


\section{Appendix A: Statistical indicators and criteria}

Table A1. Definitions of the statistics used in this work. $\left(o_{i}\right)_{i}$ and $\left(c_{i}\right)_{i}$ are the observed and the simulated concentrations at time and location $i$, respectively. $n$ is the number of data.

\begin{tabular}{ll}
\hline Statistical indicator & Definition \\
\hline Root-mean-square error (RMSE) & $\sqrt{\frac{1}{n} \sum_{i=1}^{n}\left(c_{i}-o_{i}\right)^{2}}$ \\
\hline Correlation (Corr) & $\frac{\sum_{i=1}^{n}\left(c_{i}-\bar{c}\right)\left(o_{i}-\bar{o}\right)}{\sqrt{\sum_{i=1}^{n}\left(c_{i}-\bar{c}\right)^{2}} \sqrt{\sum_{i=1}^{n}\left(o_{i}-\bar{o}\right)^{2}}}$ \\
\hline Mean fractional bias (MFB) & $\frac{1}{n} \sum_{i=1}^{n} \frac{c_{i}-o_{i}}{\left(c_{i}+o_{i}\right) / 2}$ \\
\hline Mean fractional error (MFE) & $\frac{1}{n} \sum_{i=1}^{n} \frac{\left|c_{i}-o_{i}\right|}{\left(c_{i}+o_{i}\right) / 2}$ \\
\hline
\end{tabular}

Table A2. Boylan and Russell criteria.

\begin{tabular}{lcc}
\hline Criteria & Performance criterion & Goal criterion \\
\hline IMFB| & $\leq 60 \%$ & $\leq 30 \%$ \\
MFE & $\leq 75 \%$ & $\leq 50 \%$ \\
\hline
\end{tabular}




\section{Appendix B: Single-step aging of I/S-VOCs (Couvidat et} al., 2012)

The reactions below describe the single-step aging of I/SVOCs following Couvidat et al. (2012).

$\mathrm{POAlP}+\mathrm{OH} \stackrel{k}{\rightarrow} \mathrm{SOAlP}$

$\mathrm{POAmP}+\mathrm{OH} \stackrel{k}{\rightarrow} \mathrm{SOAmP}$,

$\mathrm{POAhP}+\mathrm{OH} \stackrel{k}{\rightarrow} \mathrm{SOAhP}$,

with $k=2.0 \times 10^{-11} \mathrm{~cm}^{3}$ molecule ${ }^{-1} \mathrm{~s}^{-1}$.

Table B1. Properties of the primary and secondary anthropogenic I/S-VOCs. The molecular weights are in $\mathrm{g} \mathrm{mol}^{-1} . \Delta \mathrm{H}_{\mathrm{vap}}$ is the enthalpy of vaporization in $\mathrm{KJ} \mathrm{mol}^{-1}$, which describes the temperature dependance of the saturation pressure $C^{*}$.

\begin{tabular}{lccrrrr}
\hline Surrogate & Emission fraction & Molecular weight & $\log _{10}\left(C^{*}\right)$ at $298 \mathrm{~K}$ & $\Delta \mathrm{H}_{\mathrm{vap}}$ & $\mathrm{OM} / \mathrm{OC}$ & $\mathrm{O} / \mathrm{C}$ \\
\hline POAlP & 0.25 & 280 & -0.04 & 106.0 & 1.3 & 0.15 \\
POAmP & 0.32 & 280 & 1.94 & 91.0 & 1.3 & 0.15 \\
POAhP & 0.43 & 280 & 3.51 & 79.0 & 1.3 & 0.15 \\
\hline SOAlP & - & 392 & -2.04 & 106.0 & 1.82 & 0.56 \\
SOAmP & - & 392 & -0.06 & 91.0 & 1.82 & 0.56 \\
SOAhP & - & 392 & 1.51 & 79.0 & 1.82 & 0.56
\end{tabular}


Appendix C: Multi-step aging of I/S-VOCs (Koo et al.,

2014)

The reactions below describe the multi-step aging of I/S-

VOCs following Koo et al. (2014).

$\mathrm{VAP} 1+\mathrm{OH} \stackrel{k}{\rightarrow} 0.864 \mathrm{VAP} 0+0.142 \mathrm{VAS} 0$,

$\mathrm{VAP} 2+\mathrm{OH} \stackrel{k}{\rightarrow} 0.877 \mathrm{VAP} 1+0.129 \mathrm{VAS} 1$,

$\mathrm{VAP} 3+\mathrm{OH} \stackrel{k}{\rightarrow} 0.889 \mathrm{VAP} 2+0.116 \mathrm{VAS} 2$,

$\mathrm{AP} 4+\mathrm{OH} \stackrel{k}{\rightarrow} 0.869 \mathrm{VAP} 3+0.137 \mathrm{VAS} 3$,

with $k=4.0 \times 10^{-11} \mathrm{~cm}^{3}$ molecule $\mathrm{e}^{-1} \mathrm{~s}^{-1}$.

Table C1. Properties of the VBS species (the primary and secondary anthropogenic SVOCs). The molecular weights are in $\mathrm{g} \mathrm{mol}^{-1}$. $\Delta \mathrm{H}_{\mathrm{vap}}$ is the enthalpy of vaporization in $\mathrm{KJ} \mathrm{mol}^{-1}$, which describes the temperature dependance of the saturation pressure $C^{*}$.

\begin{tabular}{lccrrrr}
\hline Surrogate & Emission fraction & Molecular weight & $\log _{10}\left(C^{*}\right)$ at $298 \mathrm{~K}$ & $\Delta \mathrm{H}_{\text {vap }}$ & $\mathrm{OM} / \mathrm{OC}$ & $\mathrm{O} / \mathrm{C}$ \\
\hline VAP0 & 0.15 & 278 & -1 & 96.0 & 1.36 & 0.16 \\
VAP1 & 0.20 & 275 & 0 & 85.0 & 1.31 & 0.12 \\
VAP2 & 0.31 & 272 & 1 & 74.0 & 1.26 & 0.07 \\
VAP3 & 0.20 & 268 & 2 & 63.0 & 1.21 & 0.03 \\
VAP4 & 0.14 & 266 & 3 & 55.0 & 1.17 & 0.00 \\
\hline VAS0 & - & 172 & -1 & 35 & 2.05 & 0.70 \\
VAS1 & - & 167 & 0 & 35 & 1.92 & 0.60 \\
VAS2 & - & 163 & 1 & 35 & 1.81 & 0.51 \\
VAS3 & - & 158 & 2 & 35 & 1.70 & 0.43 \\
VAS4 & - & 153 & 3 & 35 & 1.59 & 0.34 \\
\hline
\end{tabular}


Appendix D: Multi-step aging of I/S-VOCs from residential heating (Ciarelli et al., 2017b)

The reactions below describe the multi-step aging of I/SVOCs following Ciarelli et al. (2017a).

$$
\begin{aligned}
& \mathrm{BBPOA} 4+\mathrm{OH} \stackrel{k}{\rightarrow} \mathrm{BBSOA} 3, \quad \text { (D1) } \\
& \mathrm{BBPOA} 3+\mathrm{OH} \stackrel{k}{\rightarrow} \mathrm{BBSOA} 2, \\
& \mathrm{BBPOA} 2+\mathrm{OH} \stackrel{k}{\rightarrow} \mathrm{BBSOA} 1, \\
& \mathrm{BBPOA} 1+\mathrm{OH} \stackrel{k}{\rightarrow} \mathrm{BBSOA} 0, \\
& \mathrm{BBSOA} 3+\mathrm{OH} \stackrel{k}{\rightarrow} \mathrm{BBSOA} 2, \quad \text { (D5) } \\
& \mathrm{BBSOA} 2+\mathrm{OH} \stackrel{k}{\rightarrow} \mathrm{BBSOA} 1, \\
& \mathrm{BBSOA} 1+\mathrm{OH} \stackrel{k}{\rightarrow} \mathrm{BBSOA} 0, \\
& \mathrm{NTVOCs}+\mathrm{OH} \stackrel{k}{\rightarrow} 0.143 \mathrm{BB} 3 \mathrm{SOA} 4+0.097 \mathrm{BB} 3 \mathrm{SOA} 3, \\
& +0.069 \mathrm{BB} 3 \mathrm{SOA} 2+0.011 \mathrm{BB} 3 \mathrm{SOA} 1 \\
& \mathrm{BB} 3 \mathrm{SOA} 4+\mathrm{OH} \stackrel{k}{\rightarrow} \mathrm{BB} 3 \mathrm{SOA} 3, \quad \text { (D9) } \\
& \mathrm{BB} 3 \mathrm{SOA} 3+\mathrm{OH} \stackrel{k}{\rightarrow} \mathrm{BB} 3 \mathrm{SOA} 2, \quad \text { (D10) } \\
& \mathrm{BB} 3 \mathrm{SOA} 2+\mathrm{OH} \stackrel{k}{\rightarrow} \mathrm{BB} 3 \mathrm{SOA} 1, \quad \text { (D11) } \\
& \mathrm{BB} 3 \mathrm{SOA} 1+\mathrm{OH} \stackrel{k}{\rightarrow} \mathrm{BB} 3 \mathrm{SOA} 0, \quad \text { (D12) }
\end{aligned}
$$

Table D1. Properties of the VBS species (the NTVOCs and primary and secondary RH-I/S-VOCs). The molecular weights are in $g$ mol ${ }^{-1}$. $\Delta \mathrm{H}_{\text {vap }}$ is the enthalpy of vaporization in $\mathrm{KJ} \mathrm{mol}^{-1}$, which describes the temperature dependance of the saturation pressure $C^{*}$.

\begin{tabular}{lccrrrr}
\hline Surrogate & Emission fraction & Molecular weight & $\log _{10}\left(C^{*}\right)$ at $298 \mathrm{~K}$ & $\Delta \mathrm{H}_{\text {vap }}$ & $\mathrm{OM} / \mathrm{OC}$ & $\mathrm{O} / \mathrm{C}$ \\
\hline NTVOCs & 4.75 & 113 & 6 & - & - & - \\
\hline BBPOA0 & 0.20 & 216 & -1 & 85.0 & 1.64 & 0.37 \\
BBPOA1 & 0.10 & 216 & 0 & 77.5 & 1.53 & 0.29 \\
BBPOA2 & 0.10 & 216 & 1 & 70.0 & 1.44 & 0.22 \\
BBPOA3 & 0.20 & 216 & 2 & 62.5 & 1.36 & 0.15 \\
BBPOA4 & 0.40 & 215 & 3 & 55.0 & 1.28 & 0.09 \\
\hline BBSOA0 & - & 194 & -1 & 35.0 & 1.80 & 0.50 \\
BBSOA1 & - & 189 & 0 & 35.0 & 1.70 & 0.43 \\
BBSOA2 & - & 184 & 1 & 35.0 & 1.61 & 0.36 \\
BBSOA3 & - & 179 & 2 & 35.0 & 1.53 & 0.29 \\
BB3SOA0 & - & 149 & -1 & 35.0 & 2.48 & 1.05 \\
BB3SOA1 & - & 144 & 0 & 35.0 & 2.29 & 0.90 \\
BB3SOA2 & - & 140 & 1 & 35.0 & 2.12 & 0.76 \\
BB3SOA3 & - & 135 & 2 & 35.0 & 1.96 & 0.63 \\
BB3SOA4 & - & 131 & 3 & 35.0 & 1.82 & 0.52 \\
\hline
\end{tabular}


Appendix E: Maps of $\mathrm{OM}_{1}$ concentrations and differences between simulations.

(a)

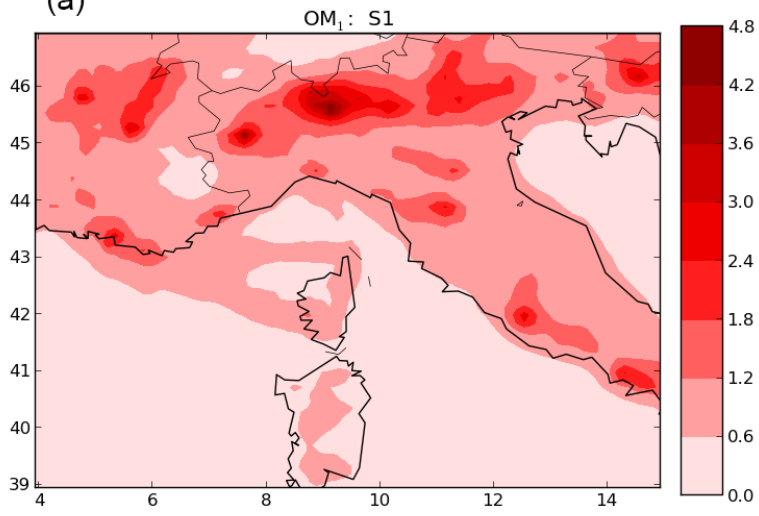

(c)

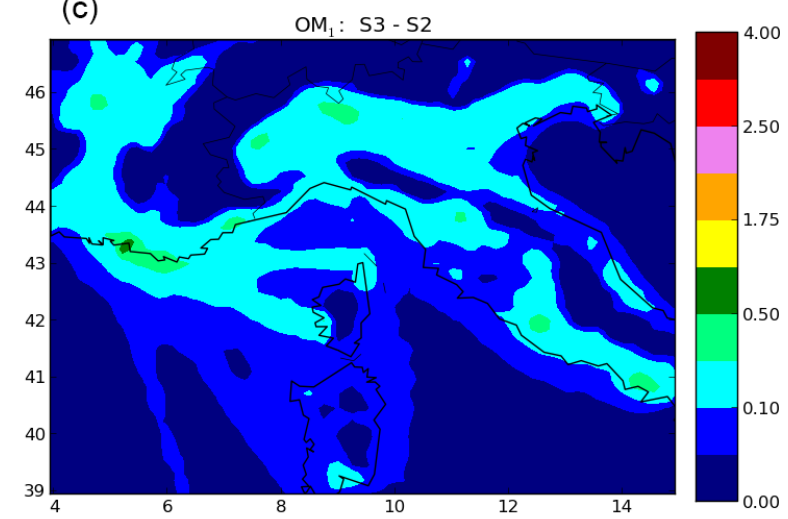

(b)

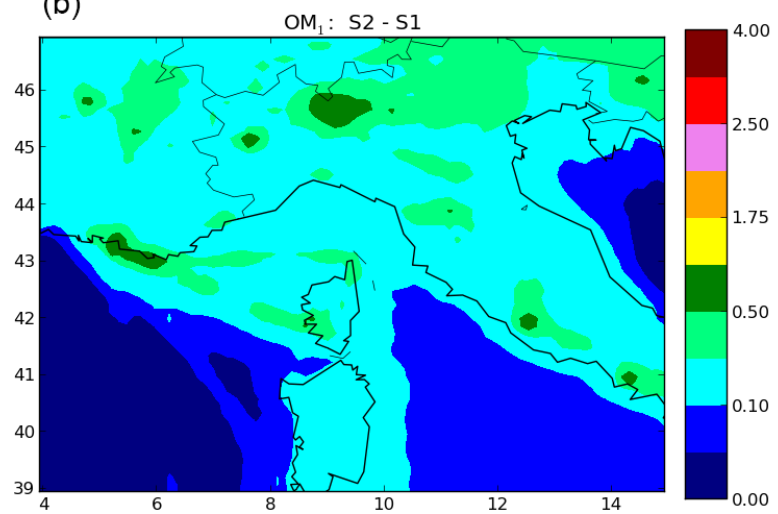

(d)

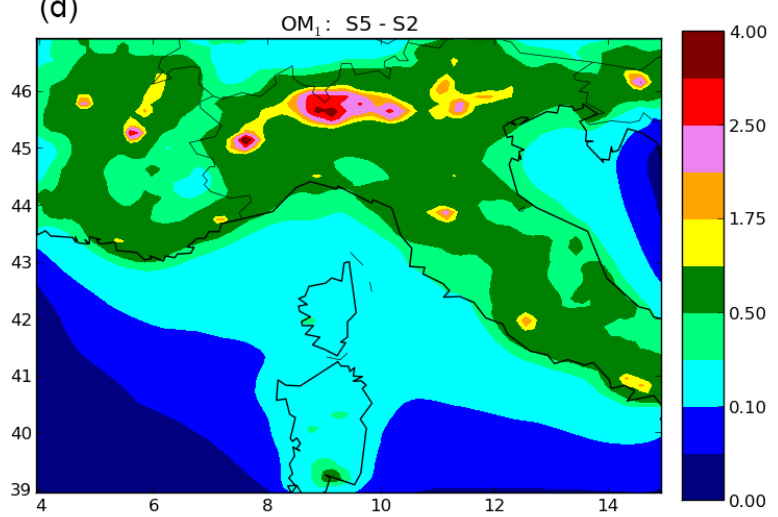

Figure E1. Maps of the concentrations of $\mathrm{OM}_{1}\left(\mu \mathrm{g} \mathrm{m}{ }^{-3}\right)$ averaged from January to March 2014 using S1 (a) and the absolute difference of $\mathrm{OM}_{1}$ concentrations between S2 and S1 (b, impact of volatility), S3 and S2 (c, impact of multi-step aging), and S5 and S2 (d, impact of increasing $R_{\mathrm{RH}}$ from 1.5 to 4$)$. 
Author contributions. MC, KS and MM performed the simulations. The other co-authors performed experiments and carried out measurements.

Competing interests. The authors declare that they have no conflict of interest.

Special issue statement. This article is part of the special issue "CHemistry and AeRosols Mediterranean EXperiments (ChArMEx) (ACP/AMT inter-journal SI)". It is not associated with a conference.

Acknowledgements. This research was funded by the French National Research Agency (ANR) projects SAF-MED (grant ANR-12-BS06-0013). It is part of the ChArMEx project supported by ADEME, CNRS-INSU, CEA and Météo-France through the multidisciplinary programme MISTRALS (Mediterranean Integrated STudies at Regional And Local Scales). It contributes to ChArMEx work packages 1 and 2 on emissions and aerosol aging, respectively. The ACSM at Ersa was funded by the CORSiCA project, which was funded by the Collectivité Territoriale de Corse through the Fonds Européen de Développement Régional of the European Operational Program 2007-2013 and the Contrat de Plan Etat-Région. Eric Hamounou is acknowledged for his great help in setting up the Ersa station. We thank François Gheusi for the measurements of ozone concentrations. CEREA is a member of the Institut Pierre Simon Laplace (IPSL).

Edited by: Matthias Beekmann

Reviewed by: two anonymous referees

\section{References}

Aiken, A., DeCarlo, P., Krol, J., Worsno, D., Huffma, J., Docherty, K., Ulbrich, I., Mohr, C., Kimmel, J., Sueper, D., Sun, Y., Zhang, Q., Trimborn, A., Northway, M., Ziemann, P., Canagaratna, M., Onasch, T., Alfarra, M., Prevot, A., Dommen, J., Duplissy, J., Metzger, A., Baltensperger, U., and Jimenez, J.: $\mathrm{O} / \mathrm{C}$ and OM/OC Ratios of Primary, Secondary, and Ambient Organic Aerosols with High-Resolution Time-of-Flight Aerosol Mass Spectrometry, Environ. Sci. Technol., 42, 4478-4485, https://doi.org/10.1021/es703009q, 2008.

Bergström, R., Denier van der Gon, H. A. C., Prévôt, A. S. H., Yttri, K. E., and Simpson, D.: Modelling of organic aerosols over Europe (2002-2007) using a volatility basis set (VBS) framework: application of different assumptions regarding the formation of secondary organic aerosol, Atmos. Chem. Phys., 12, 8499-8527, https://doi.org/10.5194/acp-12-8499-2012, 2012.

Boylan, J. W. and Russell, A. G.: PM and light extinction model performance metrics, goals, and criteria for threedimensional air quality models, Atmos. Environ., 40, 49464959, https://doi.org/10.1016/j.atmosenv.2005.09.087, 2006.

Bruns, E. A., El Haddad, I., Slowik, J. G., Kilic, D., Klein, F., Baltensperger, U., and Prévôt, A. S. H.: Identification of significant precursor gases of secondary organic aerosols from residential wood combustion, Sci. Rep., 6, 27881, https://doi.org/10.1038/srep27881, 2016.

Byun, D. and Ching, J.: Science algorithms of the EPA Models-3 Community Multiscale Air Quality (CMAQ) Modeling System, environmental Protection Agency, Research Triangle Park, NC, 1999.

Canagaratna, M. R., Jimenez, J. L., Kroll, J. H., Chen, Q., Kessler, S. H., Massoli, P., Hildebrandt Ruiz, L., Fortner, E., Williams, L. R., Wilson, K. R., Surratt, J. D., Donahue, N. M., Jayne, J. T., and Worsnop, D. R.: Elemental ratio measurements of organic compounds using aerosol mass spectrometry: characterization, improved calibration, and implications, Atmos. Chem. Phys., 15, 253-272, https://doi.org/10.5194/acp-15-253-2015, 2015.

Canonaco, F., Slowik, J. G., Baltensperger, U., and Prévôt, A. S. H.: Seasonal differences in oxygenated organic aerosol composition: implications for emissions sources and factor analysis, Atmos. Chem. Phys., 15, 6993-7002, https://doi.org/10.5194/acp15-6993-2015, 2015.

Cappa, C. D. and Jimenez, J. L.: Quantitative estimates of the volatility of ambient organic aerosol, Atmos. Chem. Phys., 10, 5409-5424, https://doi.org/10.5194/acp-10-5409-2010, 2010.

Cholakian, A., Beekmann, M., Colette, A., Coll, I., Siour, G., Sciare, J., Marchand, N., Couvidat, F., Pey, J., Gros, V., Sauvage, S., Michoud, V., Sellegri, K., Colomb, A., Sartelet, K., Langley DeWitt, H., Elser, M., Prévôt, A. S. H., Szidat, S., and Dulac, F.: Simulation of fine organic aerosols in the western Mediterranean area during the ChArMEx 2013 summer campaign, Atmos. Chem. Phys., 18, 7287-7312, https://doi.org/10.5194/acp18-7287-2018, 2018.

Chrit, M., Sartelet, K., Sciare, J., Pey, J., Marchand, N., Couvidat, F., Sellegri, K., and Beekmann, M.: Modelling organic aerosol concentrations and properties during ChArMEx summer campaigns of 2012 and 2013 in the western Mediterranean region, Atmos. Chem. Phys., 17, 12509-12531, https://doi.org/10.5194/acp-17-12509-2017, 2017.

Ciarelli, G., Aksoyoglu, S., El Haddad, I., Bruns, E. A., Crippa, M., Poulain, L., Äijälä, M., Carbone, S., Freney, E., O’Dowd, C., Baltensperger, U., and Prévôt, A. S. H.: Modelling winter organic aerosol at the European scale with CAMx: evaluation and source apportionment with a VBS parameterization based on novel wood burning smog chamber experiments, Atmos. Chem. Phys., 17, 7653-7669, https://doi.org/10.5194/acp17-7653-2017, 2017a.

Ciarelli, G., El Haddad, I., Bruns, E., Aksoyoglu, S., Möhler, O., Baltensperger, U., and Prévôt, A. S. H.: Constraining a hybrid volatility basis-set model for aging of wood-burning emissions using smog chamber experiments: a box-model study based on the VBS scheme of the CAMx model (v5.40), Geosci. Model Dev., 10, 2303-2320, https://doi.org/10.5194/gmd-102303-2017, 2017b.

Couvidat, F. and Sartelet, K.: The Secondary Organic Aerosol Processor (SOAP v1.0) model: a unified model with different ranges of complexity based on the molecular surrogate approach, Geosci. Model Dev., 8, 1111-1138, https://doi.org/10.5194/gmd8-1111-2015, 2015.

Couvidat, F., Debry, É., Sartelet, K., and Seigneur, C.: A hydrophilic/hydrophobic organic $\left(\mathrm{H}^{2} \mathrm{O}\right)$ model: Model development, evaluation and sensitivity analysis, J. Geophys. Res., 117, D10304, https://doi.org/10.1029/2011JD017214, 2012. 
Couvidat, F., Kim, Y., Sartelet, K., Seigneur, C., Marchand, N., and Sciare, J.: Modeling secondary organic aerosol in an urban area: application to Paris, France, Atmos. Chem. Phys., 13, 983-996, https://doi.org/10.5194/acp-13-983-2013, 2013a.

Couvidat, F., Sartelet, K., and Seigneur, C.: Investigating the impact of aqueous-phase chemistry and wet deposition on organic aerosol formation using a molecular surrogate modeling approach, Environ. Sci. Technol., 47, 914-922, https://doi.org/10.1021/es3034318, 2013b.

Couvidat, F., Bessagnet, B., Garcia-Vivanco, M., Real, E., Menut, L., and Colette, A.: Development of an inorganic and organic aerosol model (CHIMERE 2017 $\beta$ v1.0): seasonal and spatial evaluation over Europe, Geosci. Model Dev., 11, 165-194, https://doi.org/10.5194/gmd-11-165-2018, 2018.

Crenn, V., Sciare, J., Croteau, P. L., Verlhac, S., Fröhlich, R., Belis, C. A., Aas, W., Äijälä, M., Alastuey, A., Artiñano, B., Baisnée, D., Bonnaire, N., Bressi, M., Canagaratna, M., Canonaco, F., Carbone, C., Cavalli, F., Coz, E., Cubison, M. J., Esser-Gietl, J. K., Green, D. C., Gros, V., Heikkinen, L., Herrmann, H., Lunder, C., Minguillón, M. C., Mocnik, G., O’Dowd, C. D., Ovadnevaite, J., Petit, J.-E., Petralia, E., Poulain, L., Priestman, M., Riffault, V., Ripoll, A., Sarda-Estève, R., Slowik, J. G., Setyan, A., Wiedensohler, A., Baltensperger, U., Prévôt, A. S. H., Jayne, J. T., and Favez, O.: ACTRIS ACSM intercomparison - Part 1: Reproducibility of concentration and fragment results from 13 individual Quadrupole Aerosol Chemical Speciation Monitors (Q-ACSM) and consistency with co-located instruments, Atmos. Meas. Tech., 8, 5063-5087, https://doi.org/10.5194/amt-8-50632015, 2015.

Crippa, M., Canonaco, F., Lanz, V. A., Äijälä, M., Allan, J. D., Carbone, S., Capes, G., Ceburnis, D., Dall'Osto, M., Day, D. A., DeCarlo, P. F., Ehn, M., Eriksson, A., Freney, E., Hildebrandt Ruiz, L., Hillamo, R., Jimenez, J. L., Junninen, H., Kiendler-Scharr, A., Kortelainen, A.-M., Kulmala, M., Laaksonen, A., Mensah, A. A., Mohr, C., Nemitz, E., O'Dowd, C., Ovadnevaite, J., Pandis, S. N., Petäjä, T., Poulain, L., Saarikoski, S., Sellegri, K., Swietlicki, E., Tiitta, P., Worsnop, D. R., Baltensperger, U., and Prévôt, A. S. H.: Organic aerosol components derived from 25 AMS data sets across Europe using a consistent ME-2 based source apportionment approach, Atmos. Chem. Phys., 14, 61596176, https://doi.org/10.5194/acp-14-6159-2014, 2014

Dawson, M. L., Xu, J., Griffin, R. J., and Dabdub, D.: Development of aroCACM/MPMPO 1.0: a model to simulate secondary organic aerosol from aromatic precursors in regional models, Geosci. Model Dev., 9, 2143-2151, https://doi.org/10.5194/gmd9-2143-2016, 2016.

Debry, E., Fahey, K., Sartelet, K., Sportisse, B., and Tombette, M.: Technical Note: A new SIze REsolved Aerosol Model (SIREAM), Atmos. Chem. Phys., 7, 1537-1547, https://doi.org/10.5194/acp-7-1537-2007, 2007.

Denier van der Gon, H. A. C., Bergström, R., Fountoukis, C., Johansson, C., Pandis, S. N., Simpson, D., and Visschedijk, A. J. H.: Particulate emissions from residential wood combustion in Europe - revised estimates and an evaluation, Atmos. Chem. Phys., 15, 6503-6519, https://doi.org/10.5194/acp15-6503-2015, 2015a.

Denier van der Gon, H. A. C., Bergström, R., Fountoukis, C., Johansson, C., Pandis, S. N., Simpson, D., and Visschedijk, A. J. H.: Particulate emissions from residential wood com- bustion in Europe - revised estimates and an evaluation, Atmos. Chem. Phys., 15, 6503-6519, https://doi.org/10.5194/acp15-6503-2015, 2015b.

Donahue, N. M., Robinson, A. L., Stanier, C. O., and Pandis, S. N.: Coupled partitioning, dilution, and chemical aging of semivolatile organics, Environ. Sci. Technol., 40, 2635-2643, https://doi.org/10.1021/es052297c, 2006.

Donahue, N. M., Kroll, J. H., Pandis, S. N., and Robinson, A. L.: A two-dimensional volatility basis set - Part 2: Diagnostics of organic-aerosol evolution, Atmos. Chem. Phys., 12, 615-634, https://doi.org/10.5194/acp-12-615-2012, 2012.

Duplissy, J., DeCarlo, P. F., Dommen, J., Alfarra, M. R., Metzger, A., Barmpadimos, I., Prevot, A. S. H., Weingartner, E., Tritscher, T., Gysel, M., Aiken, A. C., Jimenez, J. L., Canagaratna, M. R., Worsnop, D. R., Collins, D. R., Tomlinson, J., and Baltensperger, U.: Relating hygroscopicity and composition of organic aerosol particulate matter, Atmos. Chem. Phys., 11, 11551165, https://doi.org/10.5194/acp-11-1155-2011, 2011.

El Haddad, I., D’Anna, B., Temime-Roussel, B., Nicolas, M., Boreave, A., Favez, O., Voisin, D., Sciare, J., George, C., Jaffrezo, J.-L., Wortham, H., and Marchand, N.: Towards a better understanding of the origins, chemical composition and aging of oxygenated organic aerosols: case study of a Mediterranean industrialized environment, Marseille, Atmos. Chem. Phys., 13, 78757894, https://doi.org/10.5194/acp-13-7875-2013, 2013.

El-Zanan, H., Lowenthal, D., Zielinska, B., Chow, J., and Kumar, N.: Determination of the organic aerosol mass to organic carbon ratio in IMPROVE samples, Chemosphere, 60, 480-496, https://doi.org/10.1016/j.chemosphere.2005.01.005, 2005.

ENVIRON: User's Guide, Comprehensive Air Quality Model with Extensions (CAMx), Version 5.40, Environ International Corporation, California, USA, 2011.

Fountoukis, C., Megaritis, A. G., Skyllakou, K., Charalampidis, P. E., Pilinis, C., Denier van der Gon, H. A. C., Crippa, M., Canonaco, F., Mohr, C., Prévôt, A. S. H., Allan, J. D., Poulain, L., Petäjä, T., Tiitta, P., Carbone, S., Kiendler-Scharr, A., Nemitz, E., O’Dowd, C., Swietlicki, E., and Pandis, S. N.: Organic aerosol concentration and composition over Europe: insights from comparison of regional model predictions with aerosol mass spectrometer factor analysis, Atmos. Chem. Phys., 14, 9061-9076, https://doi.org/10.5194/acp-14-9061-2014, 2014.

Fröhlich, R., Cubison, M. J., Slowik, J. G., Bukowiecki, N., Canonaco, F., Croteau, P. L., Gysel, M., Henne, S., Herrmann, E., Jayne, J. T., Steinbacher, M., Worsnop, D. R., Baltensperger, U., and Prévôt, A. S. H.: Fourteen months of on-line measurements of the non-refractory submicron aerosol at the Jungfraujoch (3580 m a.s.1.) - chemical composition, origins and organic aerosol sources, Atmos. Chem. Phys., 15, 11373-11398, https://doi.org/10.5194/acp-15-11373-2015, 2015.

GENEMIS: Technical Report, EUROTEC, annual report 1993, 1994.

Gentner, D., Jathar, S., Gordon, T., Bahreini, R., Day, D., El Haddad, I., Hayes, P., Pieber, S., Platt, S., de Gouw, J., Goldstein, A., Harley, R., Jimenez, J., Prévôt, A., and Robinson, A.: Review of Urban Secondary Organic Aerosol Formation from Gasoline and Diesel Motor Vehicle Emissions, Environ. Sci. Technol., 51, 1074-1093, https://doi.org/10.1021/acs.est.6b04509, 2017.

Gilardoni, S., Liu, S., Takahama, S., Russell, L. M., Allan, J. D., Steinbrecher, R., Jimenez, J. L., De Carlo, P. F., Dunlea, E. J., and 
Baumgardner, D.: Characterization of organic ambient aerosol during MIRAGE 2006 on three platforms, Atmos. Chem. Phys., 9, 5417-5432, https://doi.org/10.5194/acp-9-5417-2009, 2009.

Grieshop, A. P., Donahue, N. M., and Robinson, A. L.: Laboratory investigation of photochemical oxidation of organic aerosol from wood fires 2: analysis of aerosol mass spectrometer data, Atmos. Chem. Phys., 9, 2227-2240, https://doi.org/10.5194/acp-9-22272009, 2009.

Grosjean, D. and Friedlander, S.: Gas-particle distribution factors for organic and other pollutants in the Los Angeles atmosphere, J. Air Pollut. Control Assoc., 25, 1038-1044, 1975.

Guenther, A., Karl, T., Harley, P., Wiedinmyer, C., Palmer, P. I., and Geron, C.: Estimates of global terrestrial isoprene emissions using MEGAN (Model of Emissions of Gases and Aerosols from Nature), Atmos. Chem. Phys., 6, 3181-3210, https://doi.org/10.5194/acp-6-3181-2006, 2006.

Hayes, P. L., Carlton, A. G., Baker, K. R., Ahmadov, R., Washenfelder, R. A., Alvarez, S., Rappenglück, B., Gilman, J. B., Kuster, W. C., de Gouw, J. A., Zotter, P., Prévôt, A. S. H., Szidat, S., Kleindienst, T. E., Offenberg, J. H., Ma, P. K., and Jimenez, J. L.: Modeling the formation and aging of secondary organic aerosols in Los Angeles during CalNex 2010, Atmos. Chem. Phys., 15, 5773-5801, https://doi.org/10.5194/acp-15-5773-2015, 2015.

Horowitz, L. W., Walters, S., Mauzerall, D. L., Emmons, L. K., Rasch, P. J., Granier, C., Tie, X., Lamarque, J.-F., Schultz, M. G., Tyndall, G. S., Orlando, J. J., and Brasseur, G. P.: A global simulation of tropospheric ozone and related tracers: Description and evaluation of MOZART, version 2, J. Geophys. Res., 108, 4784, https://doi.org/10.1029/2002JD002853, 2003.

Huffman, J. A., Docherty, K. S., Mohr, C., Cubison, M. J., Ulbrich, I. M., Ziemann, P. J., Onasch, T. B., and Jimenez, J. L.: Chemically resolved volatility measurements of organic aerosol from different sources, Environ. Sci. Technol., 43, 5351-5357, https://doi.org/10.1021/Es803539d, 2009.

Jacobson, M. Z.: Development and application of a new air pollution modeling system - II. Aerosol module structure and design, Atmos. Environ., 31, 131-144, https://doi.org/10.1016/13522310(96)00202-6, 1997.

Jaeglé, L., Quinn, P. K., Bates, T. S., Alexander, B., and Lin, J.-T.: Global distribution of sea salt aerosols: new constraints from in situ and remote sensing observations, Atmos. Chem. Phys., 11, 3137-3157, https://doi.org/10.5194/acp-11-3137-2011, 2011.

Jathar, S. H., Gordon, T. D., Hennigan, C. J., Pye, H. O. T., Pouliot, G., Adams, P. J., Donahue, N. M., and Robinson, A. L.: Unspeciated organic emissions from combustion sources and their influence on the secondary organic aerosol budget in the United States, Proc. Nat. Acad. Sci. USA, 111, 10473-10478, https://doi.org/10.1073/pnas.1323740111, 2014.

Jimenez, J. L., Canagaratna, M. R., Donahue, N. M., Prevot, A. S., Zhang, Q., Kroll, J. H., DeCarlo, P. F., Allan, J. D., Coe, H., Ng, N. L., Aiken, A. C., Docherty, K. D., Ulbrich, I., Grieshop, A. P., Robinson, A. L., Duplissy, J., Smith, J. D., Wilson, K. R., Lanz, V. A., Hueglin, C., Sun, Y. L., Tian, J., Laaksonen, A., Raatikainen, T., Rautiainen, J., Vaattovaara, P., Ehn, M., Kulmala, M., Tomlinson, J. M., Collins, D. R., Cubison, M. J., Dunlea, E. J., Huffman, J. A., Onasch, T. B., Alfarra, M. R., Williams, P. I., Bower, K., Kondo, Y., Schneider, J., Drewnick, F., Borrmann, S., Weimer, S., Demerjian, K., Salcedo, D., Cottrell, L., Griffin, R., Takami, A., Miyoshi, T., Hatakeyama, S.,
Shimono, A., Sun, J. Y., Zhang, Y. M., Dzepina, K., Kimmel, J. R., Sueper, D., Jayne, J. T., Herndon, S. C., Trimborn, A. M., Williams, L. R., Wood, E. C., Kolb, C. E., Middlebrook, A. M., Baltensperger, U., and Worsnop, D. R.: Evolution of organic aerosols in the atmosphere, Science, 326, 1525-1529, https://doi.org/10.1126/science.1180353, 2009.

Kim, Y., Sartelet, K., and Seigneur, C.: Formation of secondary aerosols over Europe: comparison of two gas-phase chemical mechanisms, Atmos. Chem. Phys., 11, 583-598, https://doi.org/10.5194/acp-11-583-2011, 2011.

Kim, Y., Sartelet, K., Seigneur, C., Charron, A., Besombes, J.-L., Jaffrezo, J.-L., Marchand, N., and Polo, L.: Effect of measurement protocol on organic aerosol measurements of exhaust emissions from gasoline and diesel vehicles, Atmos. Environ., 140, 176-187, https://doi.org/10.1016/j.atmosenv.2016.05.045, 2016.

Koo, B., Knipping, E., and Yarwood, G.: 1.5-Dimensional volatility basis set approach for modeling organic aerosol in CAMx and CMAQ, Atmos. Environ., 95, 158-164, https://doi.org/10.1016/j.atmosenv.2014.06.031, 2014.

Kroll, J. H., Donahue, N. M., Jimenez, J. L., Kessler, S. H., Canagaratna, M., Wilson, K. R., Altieri, K. E., Mazzoleni, L. R., Wozniak, A. S., Bluhm, H., Mysak, E. R., Smith, J. D., Kolb, C. E., and Worsnop, D. R.: Carbon oxidation state as a metric for describing the chemistry of atmospheric organic aerosol, Nature Chem., 3, 133-139, https://doi.org/10.1038/NCHEM.948, 2011.

Lipsky, E. M. and Robinson, A. L.: Effects of dilution on fine particle mass and partitioning of semivolatile organics in diesel exhaust and wood smoke, Environ. Sci. Technol., 40, 155-162, https://doi.org/10.1021/Es050319p, 2006.

May, A. A., Levin, E. J. T., Hennigan, C. J., Riipinen, I., Lee, T., Collett, J. L., Jimenez, J. L., Kreidenweis, S. M., and Robinson, A. L.: Gas-particle partitioning of primary organic aerosol emissions: 3. Biomass burning, J. Geophys. Res.-Atmos., 118, 11327-11338, https://doi.org/10.1002/jgrd.50828, 2013a.

May, A. A., Levin, E. J. T., Hennigan, C. J., Riipinen, I., Lee, T., Collett Jr., J. L., Jimenez, J. L., Kreidenweis, S. M., and Robinson, A. L.: Gas-particle partitioning of primary organic aerosol emissions: 3. Biomass burning, J. Geophys. Res., 118, 1132711338, https://doi.org/10.1002/jgrd.50828, 2013b.

May, A. A., Presto, A. A., Hennigan, C. J., Nguyen, N. T., Gordon, T. D., and Robinson, A. L.: Gas-particle partitioning of primary organic aerosol emissions: (1) gasoline vehicle exhaust, Atmos. Environ., 77, 128-139, https://doi.org/10.1016/j.atmosenv.2013.04.060, 2013c.

May, A. A., Presto, A. A., Hennigan, C. J., Nguyen, N. T., Gordon, T. D., and Robinson, A. L.: Gas-particle partitioning of primary organic aerosol emissions: (2) diesel vehicles, Envir. Sci. Tech., 47, 8288-8296, https://doi.org/10.1021/es400782j, 2013d.

Michoud, V., Sciare, J., Sauvage, S., Dusanter, S., Léonardis, T., Gros, V., Kalogridis, C., Zannoni, N., Féron, A., Petit, J.-E., Crenn, V., Baisnée, D., Sarda-Estève, R., Bonnaire, N., Marchand, N., DeWitt, H. L., Pey, J., Colomb, A., Gheusi, F., Szidat, S., Stavroulas, I., Borbon, A., and Locoge, N.: Organic carbon at a remote site of the western Mediterranean Basin: sources and chemistry during the ChArMEx SOP2 field experiment, Atmos. Chem. Phys., 17, 8837-8865, https://doi.org/10.5194/acp17-8837-2017, 2017.

Minguillón, M., Pérez, N., Marchand, N., Bertrand, A., TemimeRoussel, B., Agrios, K., Szidat, S., van Drooge, B., Sylvestre, 
A., Alastuey, A., Reche, C., Ripoll, A., Marco, E., Grimalt, J., and Querol, X.: Secondary organic aerosol origin in an urban environment: influence of biogenic and fuel combustion precursors, Faraday Discuss., 189, 337-359, https://doi.org/10.1039/c5fd00182j, 2016.

Molteni, U., Bianchi, F., Klein, F., El Haddad, I., Frege, C., Rossi, M. J., Dommen, J., and Baltensperger, U.: Formation of highly oxygenated organic molecules from aromatic compounds, Atmos. Chem. Phys., 18, 1909-1921, https://doi.org/10.5194/acp18-1909-2018, 2018.

Murphy, B. N., Woody, M. C., Jimenez, J. L., Carlton, A. M. G., Hayes, P. L., Liu, S., Ng, N. L., Russell, L. M., Setyan, A., Xu, L., Young, J., Zaveri, R. A., Zhang, Q., and Pye, H. O. T.: Semivolatile POA and parameterized total combustion SOA in CMAQv5.2: impacts on source strength and partitioning, Atmos. Chem. Phys., 17, 11107-11133, https://doi.org/10.5194/acp-1711107-2017, 2017.

Murphy, D. M., Cziczo, D. J., Froyd, K. D., Hudson, P. K., Matthew, B. M., Middlebrook, A. M., Peltier, R. E., Sullivan, A., Thomson, D. S., and Weber, R. J.: Single-particle mass spectrometry of tropospheric aerosol particles, J. Geophys. Res., 11, 23-32, https://doi.org/10.1029/2006JD007340, 2006.

Nenes, A., Pandis, S. N., and Pilinis, C.: ISORROPIA: A new thermodynamic equilibrium model for multiphase multicomponent inorganic aerosols, Aquat. Geochem., 4, 123-152, https://doi.org/10.1023/A:1009604003981, 1998.

Ng, N. L., Herndon, S. C., Trimborn, A., Canagaratna, M. R., Croteau, P. L., Onasch, T. B., Sueper, D., Worsnop, D. R., Zhang, Q., Sun, Y. L., and Jayne, J. T.: An Aerosol Chemical Speciation Monitor (ACSM) for Routine Monitoring of the Composition and Mass Concentrations of Ambient Aerosol, Aerosol Sci. Technol., 45, 780-794, https://doi.org/10.1080/02786826.2011.560211, 2011.

Nicolas, J.: Caractérisation physico-chimique de l'aérosol troposphérique en Méditerranée : sources et devenir, $\mathrm{PhD}$ dissertation, Univ. Versailles-Saint-Quentin-en-Yvelines, 2013.

Ots, R., Young, D. E., Vieno, M., Xu, L., Dunmore, R. E., Allan, J. D., Coe, H., Williams, L. R., Herndon, S. C., Ng, N. L., Hamilton, J. F., Bergström, R., Di Marco, C., Nemitz, E., Mackenzie, I. A., Kuenen, J. J. P., Green, D. C., Reis, S., and Heal, M. R.: Simulating secondary organic aerosol from missing diesel-related intermediate-volatility organic compound emissions during the Clean Air for London (ClearfLo) campaign, Atmos. Chem. Phys., 16, 6453-6473, https://doi.org/10.5194/acp16-6453-2016, 2016.

Robinson, A. L., Donahue, N. M., Shrivastava, M. K., Weitkamp, E. A., Sage, A. M., Grieshop, A. P., Lane, T. E., Pierce, J. R., and Pandis, S. N.: Rethinking Organic Aerosols: Semivolatile Emissions and Photochemical Aging, Science, 315, 1259-1262, https://doi.org/10.1126/science.1133061, 2007.

Sartelet, K., Couvidat, F., Seigneur, C., and Roustan, Y.: Impact of biogenic emissions on air quality over Europe and North America, Atmos. Environ., 53, 131-141, 2012.

Sartelet, K., Zhu, S., Moukhtar, S., André, M., André, J. M., Gros, V., Favez, O., Brasseur, A., and Redaelli, M.: Emission of intermediate, semi and low volatile organic compounds from traffic and their impact on secondary organic aerosol concentrations over Greater Paris, Atmos. Environ., 180, 126-137, https://doi.org/10.1016/j.atmosenv.2018.02.031, 2018.
Sartelet, K. N., Debry, E., Fahey, K., Roustan, Y., Tombette, M., and Sportisse, B.: Simulation of aerosols and related species over Europe with the Polyphemus system. Part I: model-todata comparison for 2001, Atmos. Environ., 41, 6116-6131, https://doi.org/10.1016/j.atmosenv.2007.04.024, 2007.

Schwier, A. N., Rose, C., Asmi, E., Ebling, A. M., Landing, W. M., Marro, S., Pedrotti, M.-L., Sallon, A., Iuculano, F., Agusti, S., Tsiola, A., Pitta, P., Louis, J., Guieu, C., Gazeau, F., and Sellegri, K.: Primary marine aerosol emissions from the Mediterranean Sea during pre-bloom and oligotrophic conditions: correlations to seawater chlorophyll a from a mesocosm study, Atmos. Chem. Phys., 15, 7961-7976, https://doi.org/10.5194/acp15-7961-2015, 2015.

Shrivastava, M., Cappa, C., Fan, J., Goldstein, A., Guenther, A., Jimenez, J., Kuang, C., Laskin, A., Martin, S., Ng, N., Petaja, T., Pierce, J., Rasch, P., Roldin, P., Seinfeld, J., Shilling, J., Smith, J., Thornton, J., Volkamer, R., Wang, J., Worsnop, D., Zaveri, R., Zelenyuk, A., and Zhang, Q.: Recent advances in understanding secondary organic aerosol: Implications for global climate forcing, Rev. Geophys., 55, 509-559, https://doi.org/10.1002/2016RG000540, 2017.

Stockwell, C. E., Veres, P. R., Williams, J., and Yokelson, R. J.: Characterization of biomass burning emissions from cooking fires, peat, crop residue, and other fuels with high-resolution proton-transfer-reaction time-of-flight mass spectrometry, Atmos. Chem. Phys., 15, 845-865, https://doi.org/10.5194/acp-15845-2015, 2015.

Tost, H. and Pringle, K. J.: Improvements of organic aerosol representations and their effects in large-scale atmospheric models, Atmos. Chem. Phys., 12, 8687-8709, https://doi.org/10.5194/acp-12-8687-2012, 2012.

Troen, I. B. and Mahrt, L.: A simple model of the atmospheric boundary layer; sensitivity to surface evaporation, Bound.-Lay. Meteorol., 37, 129-148, https://doi.org/10.1007/BF00122760, 1986.

Tsimpidi, A. P., Karydis, V. A., Zavala, M., Lei, W., Molina, L., Ulbrich, I. M., Jimenez, J. L., and Pandis, S. N.: Evaluation of the volatility basis-set approach for the simulation of organic aerosol formation in the Mexico City metropolitan area, Atmos. Chem. Phys., 10, 525-546, https://doi.org/10.5194/acp-10-5252010, 2010.

Tsimpidi, A. P., Karydis, V. A., Pandis, S. N., and Lelieveld, J.: Global-scale combustion sources of organic aerosols: sensitivity to formation and removal mechanisms, Atmos. Chem. Phys., 17, 7345-7364, https://doi.org/10.5194/acp-17-7345-2017, 2017.

Tsimpidi, A. P., Karydis, V. A., Pozzer, A., Pandis, S. N., and Lelieveld, J.: ORACLE 2-D (v2.0): an efficient module to compute the volatility and oxygen content of organic aerosol with a global chemistry-climate model, Geosci. Model Dev., 11, 33693389, https://doi.org/10.5194/gmd-11-3369-2018, 2018.

Turpin, B. and Lim, H.-J.: Species Contributions to PM2.5 Mass Concentrations: Revisiting Common Assumptions for Estimating Organic Mass, Aerosol Sci. Technol., 35, 602-610, https://doi.org/10.1080/02786820119445, 2001.

Wong, J. P. S., Lee, A. K. Y., Slowik, J. G., Cziczo, D. J., Leaitch, W. R., Macdonald, A., and Abbatt, J. P. D.: Oxidation of ambient biogenic secondary organic aerosol by hydroxyl radicals: Effects on cloud condensation nuclei activity, Geophys. Res. Lett., 38, 22805-22811, https://doi.org/10.1029/2011GL04935, 2011. 
Woody, M. C., Baker, K. R., Hayes, P. L., Jimenez, J. L., Koo, B., and Pye, H. O. T.: Understanding sources of organic aerosol during CalNex-2010 using the CMAQ-VBS, Atmos. Chem. Phys., 16, 4081-4100, https://doi.org/10.5194/acp16-4081-2016, 2016.

Xing, L., Fu, T.-M., Cao, J. J., Lee, S. C., Wang, G. H., Ho, K. F., Cheng, M.-C., You, C.-F., and Wang, T. J.: Seasonal and spatial variability of the $\mathrm{OM} / \mathrm{OC}$ mass ratios and high regional correlation between oxalic acid and zinc in Chinese urban organic aerosols, Atmos. Chem. Phys., 13, 4307-4318, https://doi.org/10.5194/acp-13-4307-2013, 2013.

Zhang, Q., Alfarra, M., Worsnop, D., Allan, J., Coe, H., Canagaratna, M., and Jimenez, J.: Deconvolution and quantification of hydrocarbon-like and oxygenated organic aerosols based on aerosol mass spectrometry, Environ. Sci. Technol., 39, 49384952, https://doi.org/10.1021/es0485681, 2005a.

Zhang, Q., Worsnop, D. R., Canagaratna, M. R., and Jimenez, J. L.: Hydrocarbon-like and oxygenated organic aerosols in Pittsburgh: insights into sources and processes of organic aerosols, Atmos. Chem. Phys., 5, 3289-3311, https://doi.org/10.5194/acp-5-32892005, 2005b.
Zhao, Y., Nguyen, N., Presto, A., Hennigan, C., May, A., and Robinson, A.: Intermediate volatility organic compound emissions from on-road diesel vehicles: chemical composition, emission factors, and estimated secondary organic aerosol production, Environ. Sci. Technol., 49, 11516-11526, https://doi.org/10.1021/acs.est.5b02841, 2015.

Zhao, Y., Nguyen, N., Presto, A., Hennigan, C., May, A., and Robinson, A.: Intermediate volatility organic compound emissions from on-road gasoline vehicles and small off-road gasoline engines., Environ. Sci. Technol., 50, 4554-4563, https://doi.org/10.1021/acs.est.5b06247, 2016.

Zhu, S., Sartelet, K., Healy, R., and Wenger, J.: Simulation of particle diversity and mixing state over Greater Paris: A modelmeasurement inter-comparison, Faraday Discuss., 189, 547-566, https://doi.org/10.1039/C5FD00175G, 2016. 